\title{
Use of a Low-Cost Portable 3D Virtual Reality Gesture-Mediated Simulator for Training and Learning Basic Psychomotor Skills in Minimally Invasive Surgery: Development and Content Validity Study
}

Fernando Alvarez-Lopez ${ }^{1 *}, \mathrm{MD}$; Marcelo Fabián Maina ${ }^{2 *}, \mathrm{PhD}$; Francesc Saigí-Rubió ${ }^{3 *}, \mathrm{PhD}$

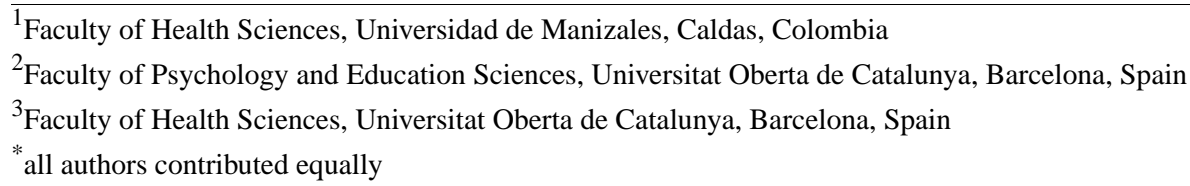

\section{Corresponding Author:}

Francesc Saigí-Rubió, $\mathrm{PhD}$

Faculty of Health Sciences

Universitat Oberta de Catalunya

Avinguda Tibidabo, 39-43

Barcelona, 08035

Spain

Phone: 34933263622

Email: fsaigi@uoc.edu

\section{Abstract}

Background: Simulation in virtual environments has become a new paradigm for surgeon training in minimally invasive surgery (MIS). However, this technology is expensive and difficult to access.

Objective: This study aims first to describe the development of a new gesture-based simulator for learning skills in MIS and, second, to establish its fidelity to the criterion and sources of content-related validity evidence.

Methods: For the development of the gesture-mediated simulator for MIS using virtual reality (SIMISGEST-VR), a design-based research (DBR) paradigm was adopted. For the second objective, 30 participants completed a questionnaire, with responses scored on a 5-point Likert scale. A literature review on the validity of the MIS training-VR (MIST-VR) was conducted. The study of fidelity to the criterion was rated using a 10-item questionnaire, while the sources of content-related validity evidence were assessed using 10 questions about the simulator training capacity and 6 questions about MIS tasks, and an iterative process of instrument pilot testing was performed.

Results: A good enough prototype of a gesture-based simulator was developed with metrics and feedback for learning psychomotor skills in MIS. As per the survey conducted to assess the fidelity to the criterion, all 30 participants felt that most aspects of the simulator were adequately realistic and that it could be used as a tool for teaching basic psychomotor skills in laparoscopic surgery (Likert score: 4.07-4.73). The sources of content-related validity evidence showed that this study's simulator is a reliable training tool and that the exercises enable learning of the basic psychomotor skills required in MIS (Likert score: 4.28-4.67).

Conclusions: The development of gesture-based 3D virtual environments for training and learning basic psychomotor skills in MIS opens up a new approach to low-cost, portable simulation that allows ubiquitous learning and preoperative warm-up. Fidelity to the criterion was duly evaluated, which allowed a good enough prototype to be achieved. Content-related validity evidence for SIMISGEST-VR was also obtained.

(J Med Internet Res 2020;22(7):e17491) doi: 10.2196/17491

\section{KEYWORDS}

simulation training; minimally invasive surgery; user-computer interface; operating rooms; medical education; computer-assisted surgery 


\section{Introduction}

\section{Background}

The emergence of minimally invasive surgery (MIS) in the mid-1980s [1] led to an increase in the number of iatrogenic bile duct injuries, as many surgeons worldwide switched from the paradigm of open surgery to these procedures with no previous training [2,3]. In the wake of these developments, simulation became valuable as a tool for learning psychomotor skills in MIS and numerous studies have demonstrated its usefulness [4,5].

Simulators for skill learning in MIS can be classified into 3 large groups: (1) traditional box trainers, (2) augmented reality simulators (hybrids), and (3) virtual reality (VR) simulators $[6,7]$. The last two are expensive and are unavailable in most universities or hospitals in developing countries [8]. The first VR simulator for MIS training was MIS training-VR (MIST-VR) [9]. In 1998, evidence for the construct validity of the device was established [10]. Later, in 2002, the evidence for prediction validity was added [4,11]. Finally, from 2002 onward, the evidence for concurrent validity was also demonstrated $[12,13]$. Recent years have seen the development of low-cost, gesture-based touchless devices that can interact with 3D virtual environments, such as the Microsoft Kinect (MS Kinect, Microsoft Corp), Leap Motion Controller (LMC; Leap Motion Inc), and the Myo armband (Thalmic Labs, Kitchener) [14].

For the development of the simulator used in this study, the researchers adopted the design-based research (DBR) paradigm, also known as design research. DBR seeks the creation and validation of useful artifacts that do not exist in nature [15] and is described by Manson [16] as "a process of using knowledge to design and create useful artefacts, and then using various rigorous methods to analyze why, or why not, a particular artefact is effective. The understanding gained during the analysis phase feeds back into and builds the body of knowledge of the discipline." DBR is a solution-oriented process that focuses on solving practical and complex real-world problems [17]. The artifacts created can be constructs (vocabulary and symbols), models (abstractions and representations), methods (algorithms and practices), instantiations (implemented and prototype systems), and better design theories [18,19]. To develop the simulator, the study followed the method proposed by Manson [16,20,21], in which using processes of abduction and deduction that detect errors in the design or function of the prototype, supports the development of improved versions until a sufficiently good enough functional product is obtained that can be subjected to validation studies [16,20-22]. These good enough devices are rarely complete and are functional systems ready to be used in practice; rather, they are innovations that define the ideas, practices, technical capabilities, and products using which systems analysis, design, implementation, and use are achieved effectively and efficiently [17].

\section{Objectives}

The first aim of this study was to describe the development of a web-based 3D VR simulator mediated by a gesture interface device (LMC) for learning basic psychomotor skills in MIS, called gesture-mediated simulator for MIS-VR (SIMISGEST-VR). The device is characterized by its portability and low cost, as well as the possibility of learning and training at any time and place (ubiquitous learning). The second aim of this study was to evaluate fidelity to the criterion and to find sources of content-related validity evidence for SIMISGEST-VR.

\section{Methods}

\section{Overview}

This is a descriptive report of the development, using a DBR paradigm, of a gesture-mediated simulator for learning basic psychomotor skills and of the prospective evaluation of the data obtained from Likert scale surveys to evaluate fidelity to the criterion and the sources of content-related evidence. To this end, the study participants rated fidelity to the criterion using a 10-item questionnaire about its ease of use, relevance as a tool for simulation in MIS, degree of correspondence between the movements of the forceps and their representation in the virtual space, and feedback. The sources of content-related validity evidence were (1) a literature review on a previously validated tool, the MIST-VR, and (2) an expert panel that answered 10 questions about the training capacity and 6 questions about each proposed task, with responses scored on a 5-point Likert scale that rated the extent to which the test content represented the domain evaluated. An iterative process of simulator development was performed using pilot testing by surgeons, engineers, and education experts until a good enough prototype was achieved.

The hypotheses were as follows:

- It is possible to develop a portable, low-cost, gesture-mediated simulator using the LMC for training and learning basic psychomotor skills in MIS.

- The 3D virtual environment and the proposed tasks showed fidelity to the criterion.

- It is possible to demonstrate sources of evidence for the content validity of the test items.

The first step of the validation process was to define the construct and proposed interpretation. In this study, the general construct is psychomotor skills in surgery, specifically basic psychomotor skills in MIS. The assumptions and proposed interpretations are that the 3D virtual environment is faithful to the criterion and the tasks adapted from the MIST-VR represent the construct that is intended to be measured. The instrument under investigation is a contactless, gesture-mediated simulator that uses the LMC (construct context). To determine the current use of gesture-mediated interfaces in surgery, especially in the field of surgical simulation, a systematic literature review was conducted [14]. Finally, as content-related validity evidence was collected, the goal was to identify whether there were any areas of construct underrepresentation or construct irrelevance.

\section{Phase 1: Initial Development of the Gesture-Mediated Simulator for Minimally Invasive Surgery-Virtual Reality}

To develop a new type of web-based 3D VR simulator mediated by a gesture interface device (LMC) for learning basic 
psychomotor skills in MIS, a group consisting of a pediatric surgeon, systems engineer, industrial designer, and specialists in education was formed. The following technical elements were assembled: an electronic device (LMC), a computer program for the development of the $3 \mathrm{D}$ environment, a computer, hardware devices with no electronic components, and a database administrator.

\section{Electronic Device: Leap Motion Controller}

In May 2012, a sensor was launched based on the principle of infrared optical tracking, which detects the positions of fine objects such as fingertips or pen tips in a Cartesian plane. Its interaction zone is an inverted cone of approximately $0.23 \mathrm{~m}^{3}$, and it has a motion detection range that fluctuates between 20 $\mathrm{mm}$ and $600 \mathrm{~mm}[23,24]$. This sensor measures $76 \mathrm{~mm} \times 30$ $\mathrm{mm} \times 13 \mathrm{~mm}$ and weighs $45 \mathrm{~g}$. It has 3 infrared emitters and 2 infrared cameras that capture the movements generated within the interaction zone [25,26]. The manufacturer reports an accuracy of $0.01 \mathrm{~mm}$ for fingertip detection, although one independent study showed an accuracy of $0.7 \mathrm{~mm}$ [27]. Although the LMC is designed mainly to detect the motion of the hands, it can track objects such as pencils and laparoscopic surgical forceps [28,29].

The LMC has been used as a tool to manipulate medical images in the fields of interventional radiology and image-guided surgery or when there is a risk of contamination through contact (eg, autopsy rooms). It has also been used for touchless control of operating lights and tables and simulation in MIS and robotic surgery using physical or VR simulators [14,28].

\section{Unity3D and Development of the Web-Based Virtual Environment Based on Minimally Invasive Surgery Training-Virtual Reality Tasks}

The 3D virtual environment with MIS tasks was created using a tool for developing games, Unity3D, which allows apps to be developed that are independent of the operating system or device [30].

The basis for the development of this environment was the MIST-VR, presented in 1997. This device is a low-cost, nonprocedural simulator that provides a large variety of metric data for analysis [31] and generates simple and abstract images that allow the training and learning of basic psychomotor maneuvers that cross many surgical disciplines [9,32,33]. The simple images allow novice learners to progress rapidly in the early phase of the basic psychomotor skills learning curve [34-36], although detailed performance analysis and feedback allow them to train alone, with no need for specialized instructors [37].

The basic psychomotor skills in MIS that can be learned using the MIST-VR are navigation-coordination, touching, grasping, stretching-traction, translocation, and electrocautery [38].

\section{Computer}

The computer displays the 3D virtual environment, records the metrics, stores them on a database, and provides feedback using graphs that show the score obtained after each exercise. The virtual environment developed runs on both $\mathrm{PC}$ and iOS operating systems.

\section{Hardware Devices}

The mechanical devices are represented by 2 MIS forceps that do not need to be functional, 2 support devices for the forceps with an entry trocar simulator, 1 support device for the LMC, and 1 pad for mounting the support devices.

During the development of the virtual environment, the types of specificity recommended by Bowman et al [39] were applied:

- Application: To design a web-based 3D virtual environment for basic psychomotor skills training in MIS

- Domain: Basic psychomotor skills in MIS

- Tasks: 6 tasks described in the MIST-VR were adopted

- Device: LMC, LEAP

- Users: Surgeons in training for learning basic psychomotor skills in MIS

\section{Phase 2: Evaluation of Fidelity to Criterion, Content-Related Validity Evidence}

\section{Subjects}

The study was performed over a period of 3 months at different locations: XXXIV Brazilian Congress of Paediatric Surgery (Campo Grande, Brazil); Hospital Vall d'Hebron (Barcelona, Spain); and Hospital Infantil de la Cruz Roja (Manizales, Colombia). A total of 22 experienced surgeons (performed more than 100 MIS procedures) and 8 pediatric and general surgery residents (referent group, performed less than 100 MIS procedures) assisted in an informative session on the characteristics of the project, watched a demonstration video of the different tasks supported by the simulator, and had 2 opportunities to perform each of the tasks on the simulator. The performance metrics were not taken into account during this study, as the emphasis was placed on the assessment of the tool by those surveyed.

\section{Content-Related Validity Evidence for a Previously Validated Tool}

The first source of content validity for the SIMISGEST-VR sought to identify the main sources of validity evidence for the MIST-VR, as well as the studies that have demonstrated such validity.

\section{Questionnaire}

First, a demographic survey was administered that included questions on the level of training as a surgeon and level of experience in MIS, as well as experience with video games. The different factors in the evaluation of fidelity to the criterion and content validity study were assessed using a Likert scale, where $1=$ strongly disagree, $2=$ disagree, $3=$ neither agree nor disagree, 4=agree, and 5=strongly agree [40].

The questionnaire to assess fidelity to the criterion evaluated 10 aspects, while the content validity rated the training capacity and the tasks. In terms of the training capacity, 6 aspects were evaluated, and each of the 6 tasks (Table 1) was assessed based on whether or not it represented a specific surgical maneuver (Multimedia Appendix 1). 


\section{Simulator, Hardware, and Software}

This study used SIMISGEST-VR with 6 tasks and their respective metrics and feedback. The hardware and software components of the simulator are described in phase 1: Development of SIMISGEST-VR of this paper.

\section{Statistics}

Normality was tested using the Shapiro-Wilk test. The distribution of the variables was not normal. The Likert scale median and interquartile range differences between the levels of education and experience were compared using the Kruskal-Wallis test. A statistically significant level $<0.05$ was established. The analysis was performed using Stata version 15.0 (StataCorp).

\section{Results}

Phase 1: Development of Gesture-Mediated Simulator for Minimally Invasive Surgery-Virtual Reality

\section{The Virtual Environment}

The virtual environment consists of the following modules:
- Registration: Collects the user's demographic information and stores it in the database

- Tutorial: Presents demonstration videos of the exercises

- Test (tasks): Supports 6 tasks, each of which corresponds to a surgical equivalent (Table 1) $[9,41]$

- Performance graphs: When an exercise is completed, the platform displays the results of the metrics in terms of the time taken to perform the exercise, precision of movement, and presence or absence of errors (immediate feedback; Figure 1). In this module, the student can look up the score obtained after each exercise and check whether or not their performance has improved (terminal feedback; Figure 2).

Except for Task 3, all tasks have the option of configuring the dominant hand during the exercise. Task 3 requires the simultaneous use of both hands and therefore both play a dominant function.

The web-based virtual environment runs on PC and iOS platforms.

These exercises are based on the instructional strategy known as drill and practice, which promotes the acquisition of knowledge or skill through repetitive practice [42].

Table 1. Description of the tasks and their surgical equivalents.

\begin{tabular}{|c|c|c|}
\hline Task $^{\mathrm{a}}$ & Description & Surgical equivalent \\
\hline Task 1: Grip and placement & $\begin{array}{l}\text { Take the sphere with one hand and move it to a } \\
\text { new location within the workspace }\end{array}$ & $\begin{array}{l}\text { Gripping and retraction of a tissue to a given position, placement } \\
\text { of clips and hemostasis, and use of extractor bags }\end{array}$ \\
\hline $\begin{array}{l}\text { Task 2: Transfer and place- } \\
\text { ment of an object }\end{array}$ & $\begin{array}{l}\text { Take the sphere, transfer it to another instrument, } \\
\text { and place it inside a hollow cylinder }\end{array}$ & Transfer of a needle between a clamp and a needle holder \\
\hline Task 3: Cross & Instruments travel along a surface in a 3D cylinder & Small intestine exploration \\
\hline $\begin{array}{l}\text { Task 4: Removal and reinser- } \\
\text { tion of instruments }\end{array}$ & $\begin{array}{l}\text { Removal of the instruments from the operative } \\
\text { site and reinsertion }\end{array}$ & $\begin{array}{l}\text { One instrument stabilizes one organ while the other is removed } \\
\text { from the field and reintroduced }\end{array}$ \\
\hline Task 5: Diathermy & $\begin{array}{l}\text { Cauterize a series of targets located in a fixed } \\
\text { sphere }\end{array}$ & Cauterize a bleeding blood vessel \\
\hline $\begin{array}{l}\text { Task 6: Target manipulation } \\
\text { and diathermy }\end{array}$ & $\begin{array}{l}\text { Take the sphere with the instrument and place it } \\
\text { inside a virtual space represented by a cube. Cau- } \\
\text { terize a series of targets with the other hand }\end{array}$ & Present and set a target to cauterize \\
\hline
\end{tabular}

${ }^{\mathrm{a}}$ Adapted from [9]. 
Figure 1. Immediate feedback.

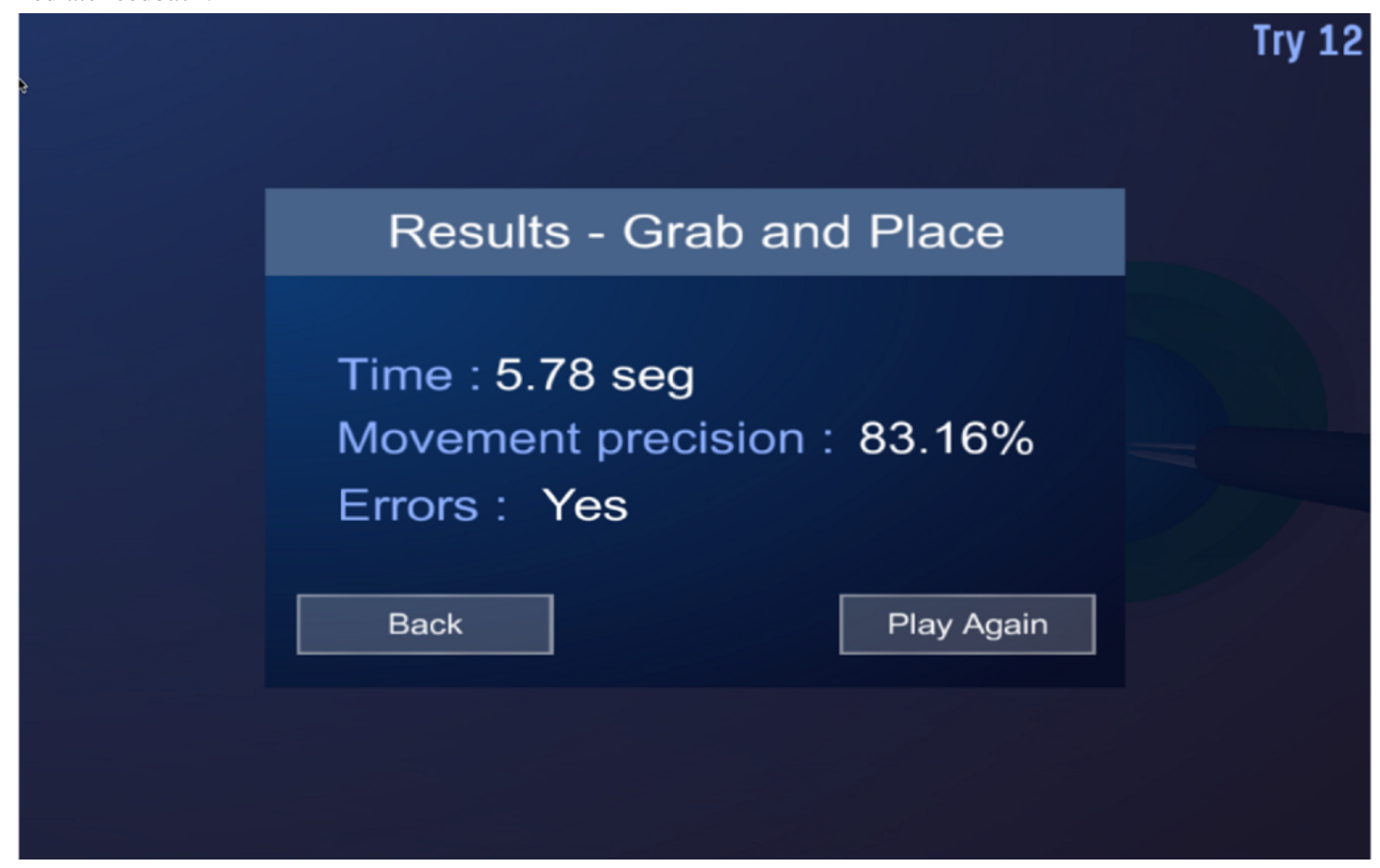

Figure 2. Performance history and terminal feedback curve.

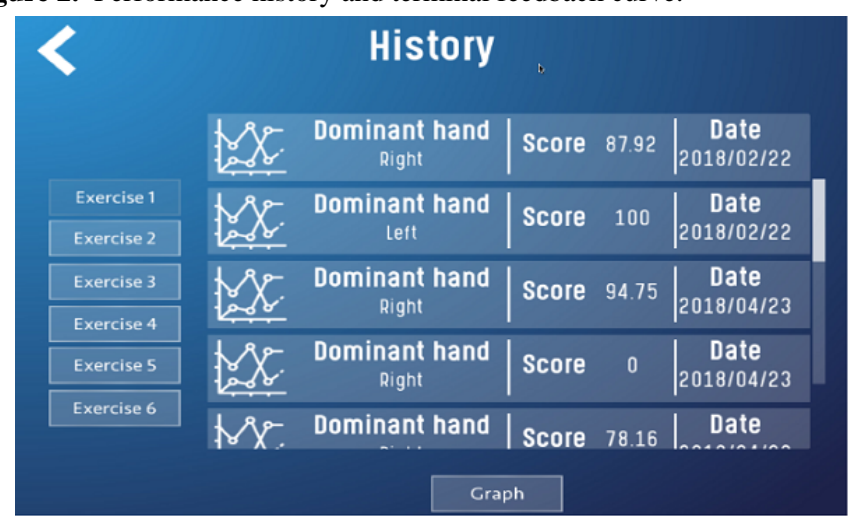

\section{Metrics}

The metrics were established using 5 parameters:

1. Time: Time taken from starting the task until completion. The time is measured only for each individual task.

2. Efficiency of movement for the right and left hand: This is the time during which the tip of the forceps is outside the ideal path, that is, the difference between the actual and the ideal path length $[10,43]$.

3. Economy of diathermy: If contact occurs with the target for more than 2 sec during the diathermy, it is considered excess burn time and is penalized as a specific error.

4. Error: The following were defined as errors [43,44]: contact of the target with a part of the forceps other than the tip: all exercises; contact of the instrument with the limits of the virtual working space: all exercises; number of contacts of the instrument with the target sphere: exercises 1 and 2; number of contacts of the instrument or the sphere with the container margins: exercises 1 and 2; number of times that the instruments made undue contact between them: exercises 3 and 4; number of times that the instruments

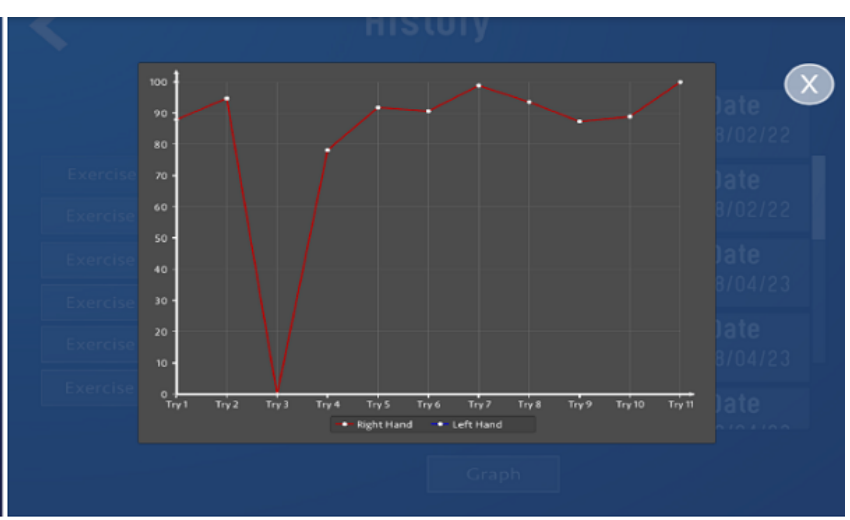

exceeded the number of contacts permitted with the oval: exercise 4; time during which the tip of the instrument remained outside the ideal path for the exercise: exercises $1,2,4$, and 6 ; diathermy of the sphere outside the stated objectives: exercises 5 and 6; excess burn time: exercises 5 and 6.

5. Final score: The final score is obtained from the sum of the results of the efficiency of movement for each hand plus the economy of diathermy and from the errors generated in each exercise. Each exercise generates different types of errors, and each error is assigned a value between 1 and 5, where 1 is the least important and 5 is the most important. For example, diathermy outside the assigned targets means an error with an assigned score of 5. The number of errors committed in each of the exercises is then counted, and this figure is multiplied by the value assigned to each error. Finally, all the figures obtained in each of the errors are added, and the final score results from subtracting the sum obtained from 100. This is expressed in the following formula: $100-\sum$ (error×value). Thus, a higher score indicates better performance. 


\section{Feedback}

The haptic sensation and the concurrent feedback are simulated using sound signals, color changes in the objects, and movement of the object when an undue collision occurs between the different components of the environment or when an error occurs during the exercise. At the end of each task, the system provides information on the presence or absence of errors, the efficacy and efficiency, and the time required (immediate feedback). At the end of each training session, the system provides a series of graphs and tables that show the performance over time; this is the terminal feedback (Figures 1 and 2).

\section{SQLite Database Engine}

The data generated by the program were initially stored on an independent Structured Query Language database engine. However, during the development, this database was integrated into the virtual environment, which facilitated the acquisition of the users' demographic data, registration of all the data provided by the metrics, and generation of reports of the users' demographic and performance data. This information is stored on the computer on which the tests are performed.

\section{Hardware}

Two laparoscopic forceps were used. These MIS forceps did not need to be functional.

In the initial phase of development, the researchers used a prototype that did not have support devices (Figure 3), but it soon became evident that the fulcrum effect was not being reproduced. For this reason, they designed support devices for the forceps, which simulate the entry portal to the abdomen (Figure 4). These devices, while generating friction when inserting and removing the forceps, limit the moment of the arms, as occurs in real surgical procedures. During the process of designing these devices, principles were prioritized, such as noninterference with the forceps reading by the LMC, portability, and low cost. A pad for mounting the support devices and the LMC was also designed, which had a 45-degree tilt on a horizontal plane.

The final artifact with all its components assembled is shown in Figure 5. It shows the fixing pad (1) for the LMC and the mounting support devices (3) for the MIS laparoscopic forceps (2), which allow simulation of the fulcrum effect; the LMC (4), responsible for detecting the movements of the instruments; and the computer, which using the software programs administers the virtual environment and the metrics and provides feedback and the final performance score on the screen (5), where the $3 \mathrm{D}$ virtual environment is displayed.

In Figure 4, the LMC has a 45-degree tilt toward the screen with respect to the horizontal plane. This arrangement was the result of a process of trial and error, which showed that setting the LMC at this angle with respect to the horizontal plane ostensibly improved the detection of the forceps. Another significant change during the design was that the original black color of the shaft of the forceps did not facilitate reading by the LMC [45]; therefore, they were painted white in the final prototype (Figure 4).

Figures 6-8 show various stages in the development of the prototype for the 3D virtual environment. As in the development of the hardware elements, the 3D virtual environment design process was iterative, so that each new version of the $3 \mathrm{D}$ virtual environment became increasingly closer to the version considered good enough in terms of the design and function.

Figure 6 shows the initial attempt at the interaction between the forceps and the basic $3 \mathrm{D}$ virtual environment. At this stage of the design, the researchers achieved capture of the virtual objects by the tip of the instruments and their transfer to a virtual container (Figure 6). The second stage of development accomplished the development of the 5 tasks in a $3 \mathrm{D}$ virtual environment characterized by rectangular geometric shapes (Figure 7). Although the researchers did have concurrent feedback based on sounds, color changes, and a sensation of collision, at that time, the metrics had not been developed. Figure 8 shows the final good enough result of the 3D virtual environment. On the basis of the feedback provided by the expert surgeons, the environment was redesigned without rectangular geometric shapes, although with abstract circular shapes that were closer to the view of the body cavities during the MIS procedure.

The changes shown in Table 2 reflect the steps in the process described by Manson [16,20], where during the development of the artifact, through iterative processes of deduction and circumscription, errors were recognized in the design or function of the prototype that required further versions to be developed until the study achieved one that was considered good enough $[16,17]$ and functional. 
Figure 3. Initial version of the prototype without support devices for the forceps.

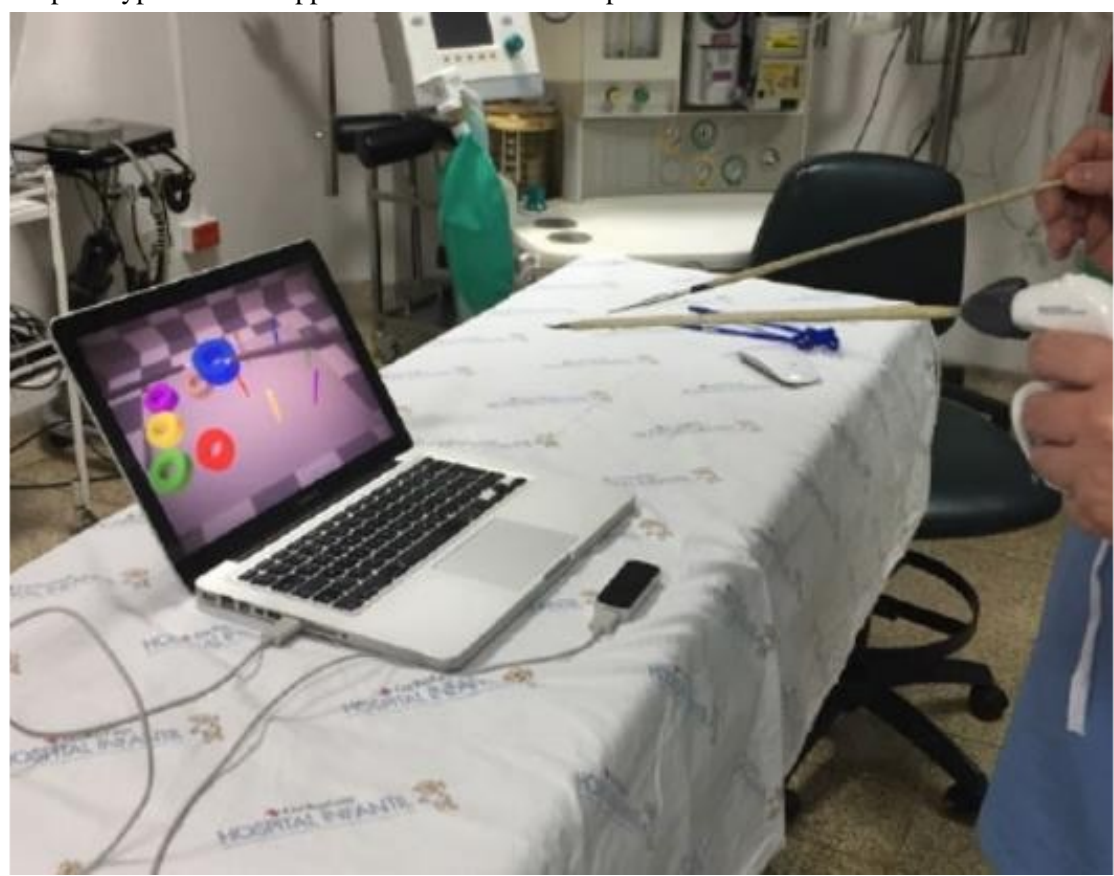

Figure 4. The final version of the simulator once the nonelectronic hardware devices had been added: the pad and support devices for the forceps and the Leap Motion Controller.

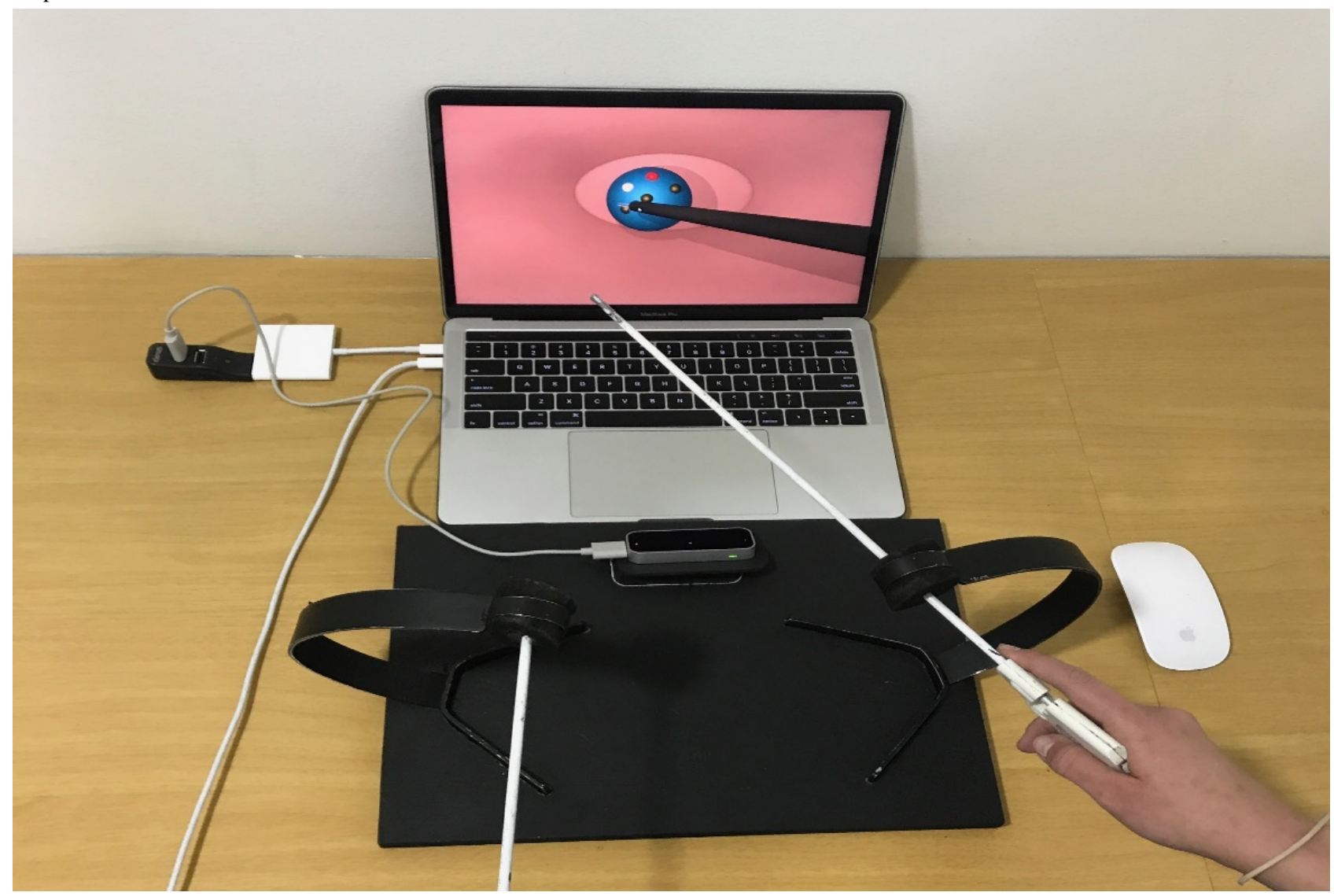


Figure 5. Diagram of the artefact.

\section{Support pad:}

- Length: $35 \mathrm{~cm}$

- Width: $25 \mathrm{~cm}$

- Height: $1.5 \mathrm{~cm}$

2. Forceps of MIS:

- Length of the stem: $33 \mathrm{~cm}$

3. Forceps support device:

- Height: $22.5 \mathrm{~cm}$

- Distance between the top of the devices: $16.5 \mathrm{~cm}$

\section{Leap Motion Controller:}

- Length: $8 \mathrm{~cm}$

- Width: $3 \mathrm{~cm}$

- Height: $12 \mathrm{~mm}$

\section{Virtual environment}

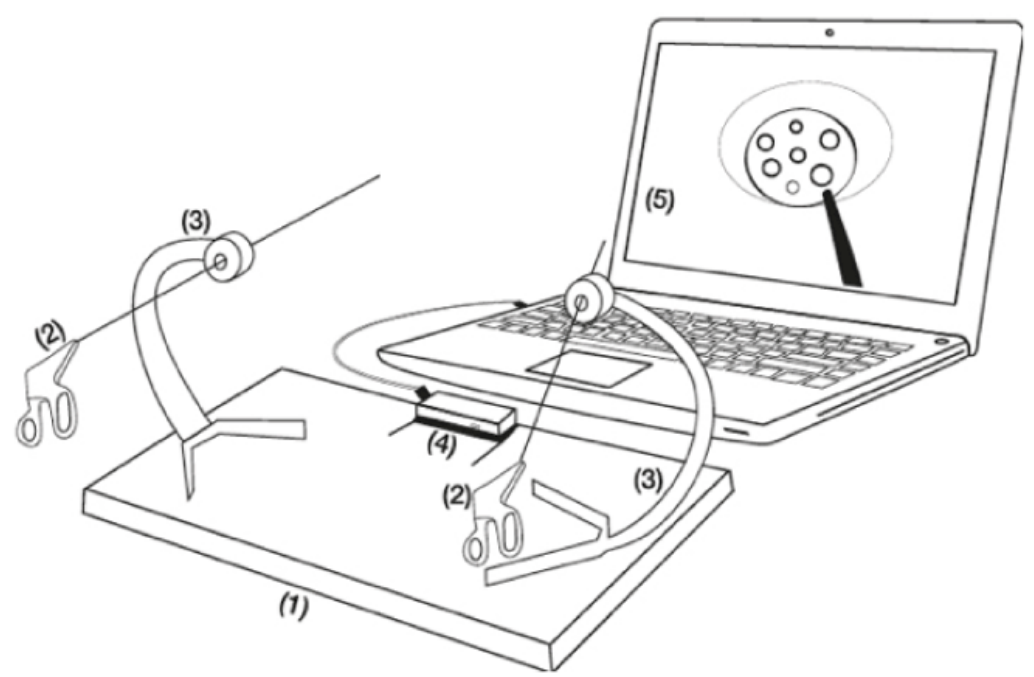

Figure 6. Initial attempts at interaction between minimally invasive surgery forceps and Leap Motion Controller within a basic 3D virtual environment.

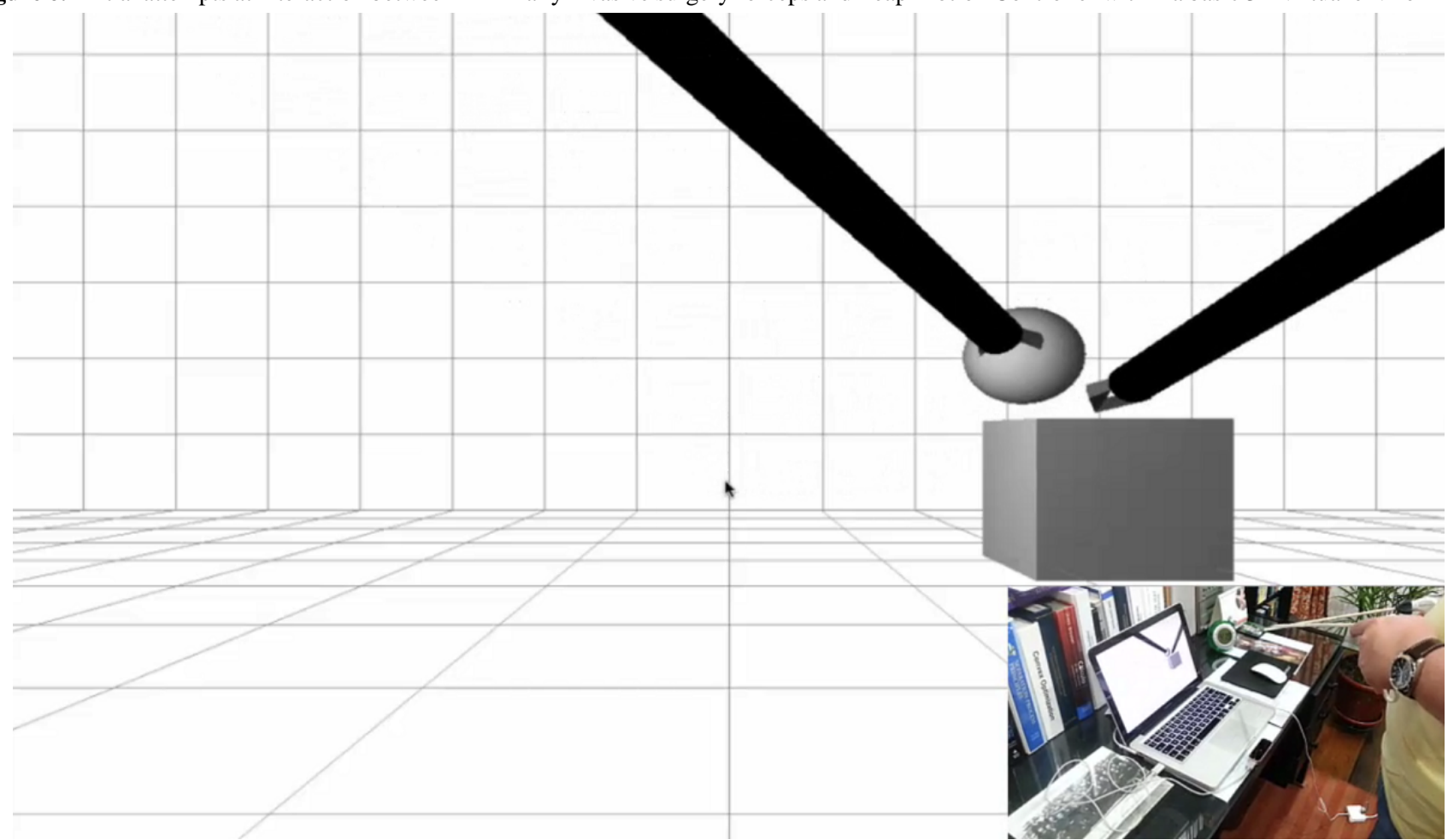


Figure 7. The first functional version of the virtual environment before the feedback given by surgeons with expertise in minimally invasive surgery.

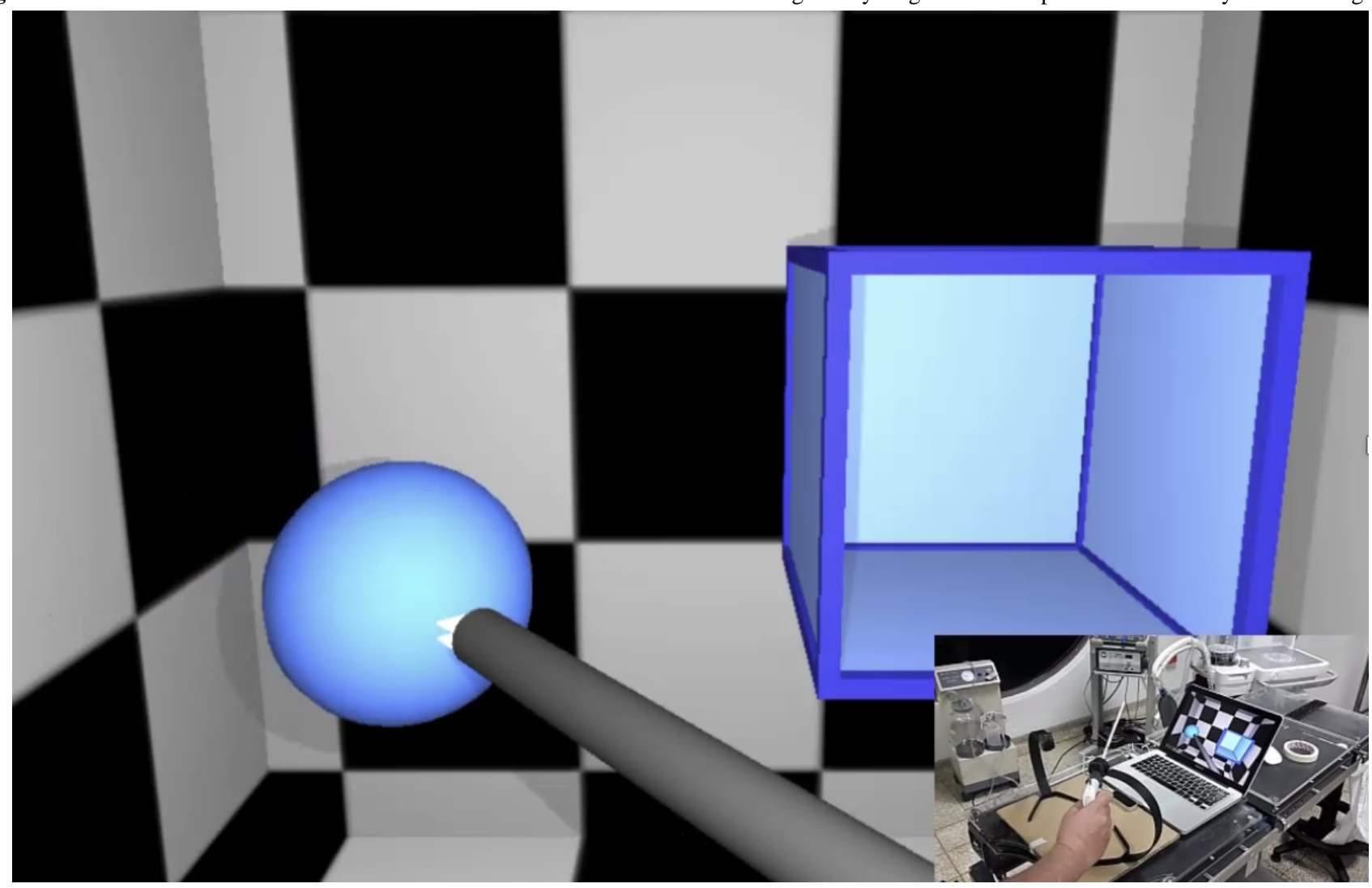

Figure 8. Good enough prototype of the web-based 3D virtual environment: Task 1.

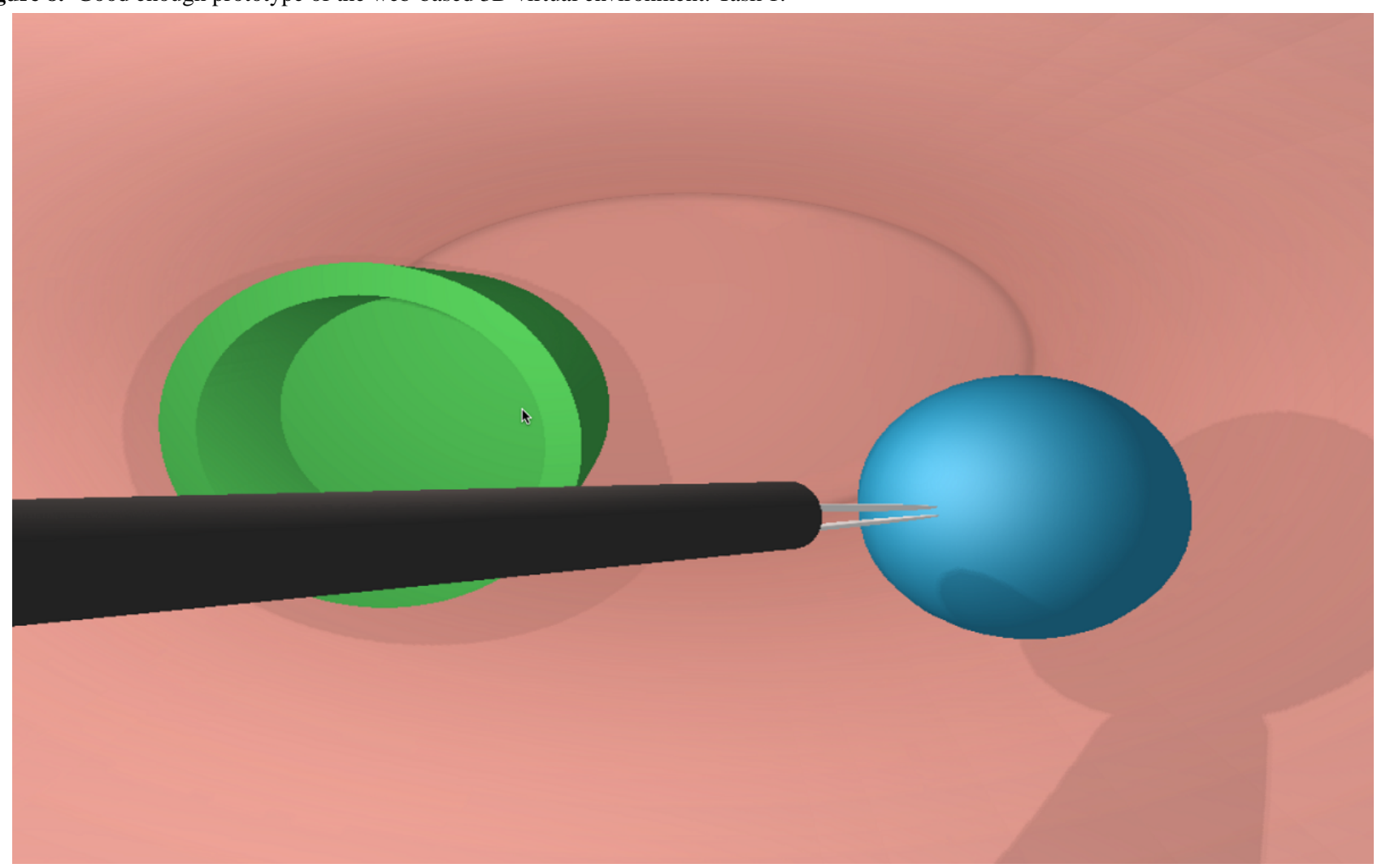


Table 2. Process of obtaining the good enough prototype.

\begin{tabular}{|c|c|c|c|c|}
\hline Element & Initial prototype & Problem & Functional prototype & Output \\
\hline MIS $^{\mathrm{a}}$ forceps & $\begin{array}{l}\text { The shaft of the forceps is } \\
\text { black }\end{array}$ & $\begin{array}{l}\text { Difficulties in the detection of } \\
\text { the forceps by the } \mathrm{LMC}^{\mathrm{b}}\end{array}$ & $\begin{array}{l}\text { The shaft of the forceps is } \\
\text { white }\end{array}$ & $\begin{array}{l}\text { Notable improvement in de- } \\
\text { tection of the forceps by the } \\
\text { LMC }\end{array}$ \\
\hline Support devices & No support devices & Fulcrum effect not reproduced & Design of support devices & $\begin{array}{l}\text { Reproduction of fulcrum ef- } \\
\text { fect }\end{array}$ \\
\hline Position of the LMC & $\begin{array}{l}\text { Completely horizontal, } 90 \\
\text { degree with regard to the } \\
\text { screen }\end{array}$ & $\begin{array}{l}\text { Difficulties in the detection of } \\
\text { the forceps by the LMC }\end{array}$ & $\begin{array}{l}\text { A forward } 45 \text {-degree angle } \\
\text { was applied with regard to } \\
\text { the screen }\end{array}$ & $\begin{array}{l}\text { Interference between the } \\
\text { forceps when detected by } \\
\text { the LMC was eliminated }\end{array}$ \\
\hline $\begin{array}{l}\text { Second prototype of the } \\
3 \mathrm{D} \text { virtual environment } \\
\text { (Figure } 7 \text { ) }\end{array}$ & $\begin{array}{l}\text { Functional environment in } \\
\text { the } 6 \text { tasks }\end{array}$ & $\begin{array}{l}\text { Quadrangular shapes in the envi- } \\
\text { ronment }\end{array}$ & $\begin{array}{l}\text { Circular shapes in the good } \\
\text { enough environment (Figure } \\
8 \text { ) }\end{array}$ & $\begin{array}{l}\text { An abstract } 3 \mathrm{D} \text { virtual envi- } \\
\text { ronment with circular shapes }\end{array}$ \\
\hline \multirow[t]{2}{*}{$\begin{array}{l}\text { Good enough environ- } \\
\text { ment (Figure 8) }\end{array}$} & \multirow[t]{2}{*}{$\begin{array}{l}\mathrm{SQL}^{\mathrm{c}} \text { database engine not } \\
\text { integrated into the simula- } \\
\text { tion software }\end{array}$} & \multirow[t]{2}{*}{$\begin{array}{l}\text { A software program should be } \\
\text { installed in addition to the simu- } \\
\text { lation program }\end{array}$} & \multirow[t]{2}{*}{$\begin{array}{l}\text { Redesign of the model and } \\
\text { data capture and storage }\end{array}$} & $\begin{array}{l}\text { Feedback and metrics com- } \\
\text { plete and integrated into the } \\
\text { SQLite }\end{array}$ \\
\hline & & & & $\begin{array}{l}\text { Integration of the SQL } \\
\text { database engine into the } \\
\text { simulation software }\end{array}$ \\
\hline
\end{tabular}

${ }^{\mathrm{a}} \mathrm{MIS}$ : minimally invasive surgery.

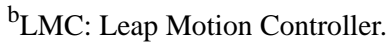

${ }^{\mathrm{c}} \mathrm{SQL}:$ Structured Query Language.

\section{Phase 2: Evaluation of Fidelity to the Criterion and Subjective Validation of SIMISGEST-VR (Content Validity)}

The next step in the process was the evaluation of fidelity to the criterion and the process of subjective content validity. The results are described below.

\section{Demographics}

A total of 30 people with an average age of 42 years (SD 2.2) participated in the study; 53\% $(n=16 / 30)$ were men. Those surveyed came from Colombia $(n=14)$, Spain $(n=8)$, Argentina $(n=3)$, Brazil $(n=2)$, Uruguay $(n=2)$, and France $(n=1)$.

Table 3 summarizes the participants' profiles according to the level of training and experience. The residents belonged to training programs in general and pediatric surgery; one of the participants was a biomedical engineer with extensive experience in the design of devices and simulators in MIS. The vast majority $(n=28 / 30,93 \%)$ of participants were right-handed, 1 was left-handed $(n=9 / 30,3 \%)$, and the other, ambidextrous $(\mathrm{n}=9 / 30,3 \%)$.

In terms of the use of video games, most $(n=22 / 30,73 \%)$ of those surveyed had no experience with these app; $62 \%(n=5 / 8)$ of those who used video games were women. Of those with experience in video games $(n=8)$, only 1 played them weekly, while the rest played them once a month $(n=3)$ or occasionally $(n=4)$. The mean age of those with no experience in video games was 44 years (SD 2.7), compared with 37 years (SD 3.5) for those with experience $(P=.16)$.

Only $33 \%(n=10 / 30)$ of the participants had experience with VR devices, and only one-third used them occasionally.

Most of the surveyed participants had previous experience with simulators. In terms of the level of operating experience, 54\% $(n=14 / 26)$ of the respondents with experience with simulators had an intermediate or advanced operating level, followed by those with a basic operating level $(n=10 / 26,38 \%)$. Among participants who had experience with simulators [26], 62\% $(n=16 / 26)$ had used physical simulators, $23 \%(n=6 / 26)$ had used hybrid simulators, and only $15 \%(n=4 / 26)$ had used VR simulators. The average age of those who had no experience with simulators was 40 years (SD 6.7), compared with 42 years (SD 2.4) for those with previous experience $(P=.83)$.

The demographic profile questionnaire can be found in Multimedia Appendix 1. 
Table 3. Demographic profile according to the level of experience and training $(\mathrm{N}=30)$.

\begin{tabular}{|c|c|c|c|c|c|c|c|}
\hline \multirow[t]{2}{*}{ Demographic variable } & \multicolumn{4}{|l|}{ Level of experience } & \multicolumn{3}{|c|}{ Level of training } \\
\hline & $\begin{array}{l}\text { Basic manipulation } \\
(\mathrm{n}=3)^{\mathrm{a}}\end{array}$ & $\begin{array}{l}\text { Basic operating } \\
\text { level }(n=11)^{b}\end{array}$ & $\begin{array}{l}\text { Intermediate operating } \\
\text { level }(n=8)^{c}\end{array}$ & $\begin{array}{l}\text { Advanced operat- } \\
\text { ing level }(n=8)^{d}\end{array}$ & $\begin{array}{l}\text { Practicing sur- } \\
\text { geon }(n=21)\end{array}$ & $\begin{array}{l}\text { Resident } \\
(\mathrm{n}=8)\end{array}$ & $\begin{array}{l}\text { Other } \\
(\mathrm{n}=1)^{\mathrm{e}}\end{array}$ \\
\hline Age (years), mean (SD) & $26(0.6)$ & $40(4.3)$ & $43(3.3)$ & $49(2.9)$ & $47(2.2)$ & $27(0.6)$ & $49\left(-{ }^{f}\right)$ \\
\hline \multicolumn{8}{|l|}{ Sex, $n$} \\
\hline Male & 0 & 3 & 5 & 8 & 15 & 0 & 1 \\
\hline Female & 3 & 8 & 3 & 0 & 6 & 8 & 0 \\
\hline \multicolumn{8}{|c|}{ Do you have regular experience with video games?, $n$} \\
\hline Yes & 1 & 1 & 4 & 2 & 6 & 1 & 1 \\
\hline No & 2 & 10 & 4 & 6 & 16 & 6 & 0 \\
\hline \multicolumn{8}{|c|}{ Do you have previous experience with MIS $^{\mathrm{g}}$ simulators?, $\mathrm{n}$} \\
\hline Yes & 2 & 10 & 6 & 8 & 19 & 7 & 0 \\
\hline No & 1 & 1 & 2 & 0 & 3 & 0 & 1 \\
\hline \multicolumn{8}{|c|}{ What type of simulator?, $n$} \\
\hline Physical & 2 & 6 & 3 & 5 & 12 & 3 & 1 \\
\hline $\begin{array}{l}\text { Hybrid and augment- } \\
\text { ed reality }\end{array}$ & 0 & 2 & 2 & 2 & 4 & 2 & 0 \\
\hline Virtual reality & 0 & 2 & 1 & 1 & 2 & 2 & 0 \\
\hline No experience & 1 & 1 & 2 & 0 & 3 & 1 & 0 \\
\hline
\end{tabular}

${ }^{\mathrm{a} B a s i c}$ manipulation of the camera and/or retraction with forceps.

${ }^{b}$ Basic operating level (cholecystectomy and appendectomy).

${ }^{\mathrm{c}}$ Intermediate operating level (fundoplication).

${ }^{\mathrm{d}}$ Advanced operating level.

${ }^{\mathrm{e} O t h e r: ~ a n ~ e n g i n e e r ~ h i g h l y ~ e x p e r i e n c e d ~ i n ~ t h e ~ d e s i g n ~ o f ~ i n s t r u m e n t s ~ a n d ~ d e v i c e s ~ f o r ~ m i n i m a l l y ~ i n v a s i v e ~ s u r g e r y ~ s i m u l a t i o n . ~}$

${ }^{f}$ Not available because there was only one observation.

${ }^{\mathrm{g}}$ MIS: minimally invasive surgery.

\section{Evaluation of Fidelity to Criterion}

Tables 4 and 5 show that there were no significant differences in the different ratings when the level of training (Table 4) or experience (Table 5) was considered.

In terms of the fidelity to the criterion, none of the respondents strongly disagreed with any of the items asked. The rating of disagree was given by one participant to the question about relevance, by another to the assessment of how the movements of the physical instruments were represented in the virtual environment, and 3 assigned this score when rating the fulcrum effect.

In terms of ease of use, $73 \%(n=22 / 30)$ and $27 \%(n=8 / 30)$ assigned a rating of 5 and 4 , respectively. The same results were obtained when the navigation menu was assessed. With regard to the relevance of the tool as a simulator, 73\% ( $n=22 / 30)$ assigned a score of 5 and $20 \%(n=6 / 30)$ assigned a score of 4 .

When assessing the capacity of the physical devices to simulate the fulcrum effect, $73 \%$ (22/30) assigned a score between 4 and $5,17 \%(\mathrm{n}=5 / 30)$ assigned a score of 3 , and $10 \%(\mathrm{n}=3 / 30)$ assigned a score of 2 . For this last rating, in terms of the level of training, 2 were practicing surgeons and 1 was a resident, whereas in terms of the level of experience, one corresponded to basic manipulation, one to intermediate operating level, and another to advanced level.

In terms of how the movements of the forceps were represented in the virtual environment, $73 \%(n=22 / 30)$ rated this as 4 or 5 , $23 \%(n=7 / 30)$ assigned a score of 3 , and only one of the participants $(n=9 / 30,3 \%)$ assigned a score of 2 (level of training=practicing surgeon and level of experience $=$ intermediate).

When assessing how appropriately the tool simulates the movements of MIS, $83 \%(n=25 / 30)$ rated the question as 4 or 5. All respondents $(n=30 / 30,100 \%)$ rated the design as attractive, with scores of 4 or 5 . Almost all surveyed respondents $(n=29 / 30,97 \%)$ assigned ratings of 4 or 5 to the innovation factor, the capacity to provide feedback, and to the question of whether the latter was adequate.

The fidelity to the criterion study questions can be found in Multimedia Appendix 1. The fidelity to the criterion study result tables can be found in Multimedia Appendix 2 . 
Table 4. Fidelity to the criterion and content validity according to the level of training.

\begin{tabular}{|c|c|c|c|c|c|c|c|}
\hline \multirow[t]{2}{*}{ Variable } & \multicolumn{2}{|c|}{ Resident $(n=8)$} & \multicolumn{2}{|c|}{$\begin{array}{l}\text { Practicing surgeon } \\
(n=21)\end{array}$} & \multicolumn{2}{|c|}{ Other $^{\mathrm{a}}(\mathrm{n}=1)$} & \multirow[t]{2}{*}{$P$ value } \\
\hline & Median & IQR & Median & IQR & Median & IQR & \\
\hline \multicolumn{8}{|l|}{ Fidelity to the criterion ${ }^{b}$} \\
\hline Ease of use & 5 & $4.5-5$ & 5 & $4-5$ & 5 & $5-5$ & .88 \\
\hline Navigation menu & 5 & $5-5$ & 5 & $4-5$ & 5 & $5-5$ & .62 \\
\hline Relevance as a learning tool & 5 & $4-5$ & 5 & $5-5$ & 5 & $5-5$ & .73 \\
\hline Fulcrum effect & 3.5 & $3-4$ & 5 & $4-5$ & 4 & $4-4$ & .13 \\
\hline Representation of the physical forceps in the virtual environment & 4 & $3-5$ & 4 & $4-5$ & 5 & $5-5$ & .56 \\
\hline Simulation of the movements in MIS ${ }^{\mathrm{c}}$ & 4 & $4-4$ & 4 & $4-5$ & 5 & $5-5$ & .18 \\
\hline Innovation & 5 & $4.5-5$ & 5 & $5-5$ & 5 & $5-5$ & .90 \\
\hline Graphic design & 4.5 & $4-5$ & 5 & $4-5$ & 5 & $5-5$ & .69 \\
\hline Feedback & 5 & $4-5$ & 5 & $5-5$ & 5 & $5-5$ & .79 \\
\hline Relevance of the feedback & 4 & $4-5$ & 5 & $4-5$ & 5 & $5-5$ & .43 \\
\hline \multicolumn{8}{|l|}{ Content validity $^{d}$} \\
\hline Hand-eye coordination & 4.5 & $4-5$ & 5 & $4-5$ & 5 & $5-5$ & .66 \\
\hline Depth perception & 4 & $3.5-5$ & 5 & $4-5$ & 5 & $5-5$ & .41 \\
\hline Basic psychomotor skills learning & 4.5 & $4-5$ & 5 & $5-5$ & 5 & $5-5$ & .42 \\
\hline Basic steps of MIS & 4 & $4-5$ & 5 & $4-5$ & 5 & $5-5$ & .64 \\
\hline Metrics & 4 & $3-5$ & 4 & $4-5$ & 5 & $5-5$ & .43 \\
\hline Ubiquitous learning & 4 & $4-5$ & 5 & $4-5$ & 5 & $5-5$ & .31 \\
\hline \multicolumn{8}{|l|}{ Tasks } \\
\hline Task 1 & 3.5 & $3-4$ & 4 & $4-5$ & 5 & $5-5$ & .19 \\
\hline Task 2 & 4 & $4-4.5$ & 4 & $3-5$ & 5 & $5-5$ & .41 \\
\hline Task 3 & 4 & $3.5-4$ & 4 & $3-5$ & 5 & $5-5$ & .40 \\
\hline Task 4 & 4 & $3-5$ & 5 & $4-5$ & 2 & $2-2$ & .21 \\
\hline Task 5 & 4.5 & $4-5$ & 5 & $4-5$ & 5 & $5-5$ & .65 \\
\hline Task 6 & 4 & $4-4$ & 5 & $4-5$ & 5 & $5-5$ & .02 \\
\hline
\end{tabular}

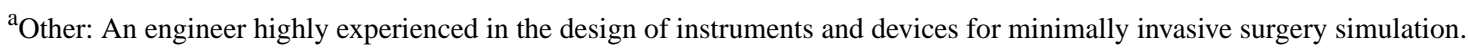

${ }^{\mathrm{b}}$ For fidelity to the criterion questions, see Multimedia Appendix 1.

${ }^{\mathrm{c}}$ MIS: minimally invasive surgery.

${ }^{\mathrm{d}}$ For content validity questions, see Multimedia Appendix 1.

${ }^{\mathrm{e}}$ For task descriptions, see Table 1. 
Table 5. Fidelity to the criterion and content validity according to the level of experience.

\begin{tabular}{|c|c|c|c|c|c|c|c|c|c|}
\hline \multirow[t]{2}{*}{ Variable } & \multicolumn{2}{|c|}{$\begin{array}{l}\text { Basic manipula- } \\
\text { tion }(\mathrm{n}=3)\end{array}$} & \multicolumn{2}{|c|}{$\begin{array}{l}\text { Basic operating } \\
\text { level }(n=11)\end{array}$} & \multicolumn{2}{|c|}{$\begin{array}{l}\text { Intermediate operating } \\
\text { level }(n=8)\end{array}$} & \multicolumn{2}{|c|}{$\begin{array}{l}\text { Advanced operating } \\
\text { level }(n=8)\end{array}$} & \multirow[t]{2}{*}{$P$ value } \\
\hline & Median & IQR & Median & IQR & Median & IQR & Median & IQR & \\
\hline \multicolumn{10}{|l|}{ Fidelity to the criterion ${ }^{a}$} \\
\hline Ease of use & 5 & $4-5$ & 5 & $4-5$ & 5 & $4.5-5$ & 4.5 & $4-5$ & .84 \\
\hline Navigation menu & 5 & $4-5$ & 5 & $5-5$ & 5 & $4.5-5$ & 4.5 & $4-5$ & .51 \\
\hline Relevance as a learning tool & 5 & $2-5$ & 5 & $4-5$ & 5 & $5-5$ & 5 & $4-5$ & .83 \\
\hline Fulcrum effect & 4 & $2-5$ & 4 & $3-5$ & 5 & $4-5$ & 4 & $4-5$ & .66 \\
\hline $\begin{array}{l}\text { Representation of the physical forceps } \\
\text { in the virtual environment }\end{array}$ & 5 & $3-5$ & 4 & $4-5$ & 4 & $3.5-5$ & 4.5 & $3-5$ & .96 \\
\hline Simulation of the movements in MIS ${ }^{b}$ & 4 & $4-4$ & 4 & $4-5$ & 4.5 & $3.5-5$ & 4 & $3.5-4.5$ & .70 \\
\hline Innovation & 5 & $3-5$ & 5 & $5-5$ & 5 & $4.5-5$ & 5 & $4.5-5$ & .95 \\
\hline Graphic design & 4 & $4-5$ & 5 & $4-5$ & 5 & $4.5-5$ & 4 & $4-5$ & .41 \\
\hline Feedback & 5 & $4-5$ & 5 & $4-5$ & 5 & $5-5$ & 4.5 & $4-5$ & .42 \\
\hline Relevance of the feedback & 4 & $4-5$ & 5 & $4-5$ & 5 & $4.5-5$ & 4.5 & $4-5$ & .66 \\
\hline \multicolumn{10}{|l|}{ Content validity ${ }^{\mathrm{c}}$} \\
\hline Hand-eye coordination & 4 & $4-5$ & 5 & $4-5$ & 5 & $5-5$ & 4.5 & $4-5$ & .77 \\
\hline Depth perception & 5 & $4-5$ & 5 & $4-5$ & 5 & $4-5$ & 4.5 & $4-5$ & .95 \\
\hline Basic psychomotor skills learning & 4 & $3-5$ & 5 & $4-5$ & 5 & $5-5$ & 5 & $4-5$ & .45 \\
\hline Basic steps of MIS & 4 & $4-5$ & 5 & $4-5$ & 5 & $4.5-5$ & 4 & $4-4.5$ & .33 \\
\hline Metrics & 4 & $3-5$ & 4 & $3-5$ & 4.5 & $4-5$ & 4.5 & $4-5$ & .75 \\
\hline Ubiquitous learning & 4 & $4-5$ & 5 & $4-5$ & 5 & $5-5$ & 4.5 & $4-5$ & .46 \\
\hline \multicolumn{10}{|l|}{ Tasks $^{d}$} \\
\hline Task 1 & 3 & $3-5$ & 4 & $3-5$ & 4 & $3.5-5$ & 4 & $3.5-4.5$ & .88 \\
\hline Task 2 & 4 & $4-5$ & 4 & $4-5$ & 4 & $3.5-5$ & 3.5 & $2-5$ & .76 \\
\hline Task 3 & 4 & $2-5$ & 4 & $3-4$ & 4.5 & $3.5-5$ & 4 & $3.5-5$ & .76 \\
\hline Task 4 & 2 & $2-5$ & 4 & $4-5$ & 5 & $5-5$ & 4 & $3.5-5$ & .18 \\
\hline Task 5 & 4 & $4-5$ & 5 & $4-5$ & 5 & $4.5-5$ & 4.5 & $4-5$ & .70 \\
\hline Task 6 & 4 & $4-4$ & 4 & $4-5$ & 5 & $5-5$ & 4.5 & $4-5$ & .12 \\
\hline
\end{tabular}

${ }^{\mathrm{a}}$ For fidelity to the criterion questions, see Multimedia Appendix 1.

${ }^{\mathrm{b}}$ MIS: minimally invasive surgery.

${ }^{\mathrm{c}}$ For content validity questions, see Multimedia Appendix 1.

${ }^{\mathrm{d}}$ For task descriptions, see Table 1.

\section{Content Validity}

Table 6 summarizes the sources of validity evidence for the MIST-VR and the studies that have demonstrated such validity.

With regard to content validity, none of the items evaluated for the training capacity were rated as 1 , although, in the case of hand-eye coordination by a practicing surgeon with an advanced operating level and the depth perception by a practicing surgeon with an intermediate operating level, the hand-eye coordination and depth perception were rated as 2 . Almost all of those surveyed $(n=28 / 30,93 \%)$ rated the hand-eye coordination as 4 or 5, while $87 \%(n=26 / 30)$ gave this score for depth perception.
The highest-rated item was the one that considered that the prototype could be a solution for ubiquitous learning in MIS: $100 \%(n=30 / 30)$ of those surveyed rated it as 4 or 5 . With regard to the evaluation of the metrics, $17 \%(n=5 / 30)$ of those surveyed rated them as 3 , while the remaining participants $(n=25 / 30)$ rated them as 4 or 5 .

Almost all respondents $(n=29 / 30,97 \%)$ considered that the SIMISGEST-VR enables learning of basic psychomotor skills in MIS, with ratings of 4 and 5; whereas, $93 \%(n=28 / 30)$ agreed that the tasks reflect the basic steps of a minimally invasive procedure, with ratings of 4 and 5 . 
An analysis of the evaluation of the tasks, in general, showed that the following were rated between 4 and 5: Task 1 received this rating from $70 \%(n=21 / 30)$ of those interviewed; Task 2 from $77 \%(n=23 / 30)$; Task 3 from $73 \%(n=22 / 30)$; Task 4 from $77 \%(n=23 / 30)$; and Task 5 and Task 6 from 90\% $(n=27 / 30)$ of the participants.
For Task 6 (Table 4), a lower score was assigned by individuals with lower levels of training $(P=.02)$.

The content validity study questions can be found in Multimedia Appendix 1. The tables of results of the content validity study can be found in Multimedia Appendix 3.

Table 6. Sources of validity evidence for the minimally invasive surgery training-virtual reality.

\begin{tabular}{ll}
\hline Source of validity evidence & Studies \\
\hline Content evidence & {$[9,10,43,46-51]$} \\
Internal structure & {$[41,43,48,52-62]$} \\
Relationship to other variables & {$[4,10,12,13,37,43,47,50-57,60,63-116]$} \\
Consequences & {$[4,11,13,43,47,49,50,54,56,57,59,69,71,73,78,79,92,104,107,108,114,117-123]$} \\
\hline
\end{tabular}

\section{Discussion}

\section{Principal Findings}

Simulation as a tool for learning psychomotor skills in MIS has become a new model for education in surgery. The use of human or animal cadavers is becoming increasingly controversial for learning surgical maneuvers [124,125], resulting in an immense growth of simulation using virtual environments as a tool for learning psychomotor skills in MIS and for the simulation of full surgical procedures $[5,126]$.

Simulators for psychomotor skills learning in MIS are classified into mechanical, hybrid/augmented reality, or VR [6,7]. Devices for gesture-based human-computer interaction are a new way of interacting with virtual environments. This study's simulator presents a new form of gesture-based simulation that is portable, low-cost, and enables ubiquitous learning and preoperative warm-up $[14,127,128]$.

\section{Development of Gesture-Mediated Simulator for Minimally Invasive Surgery-Virtual Reality}

The development of SIMISGEST-VR was based on DBR principles. It was a pragmatic process because the researchers tried to resolve the problems of portability and the high cost of simulators for learning psychomotor skills in MIS. It was grounded in both theory and the real-world context, as we designed a functional simulator based on theories on simulation-based surgical skills training. It was interactive, in that during the simulator design stage, a good enough prototype was obtained through the participation of an interdisciplinary team (pediatric surgery, systems engineering, graphic design, and experts in education and psychology), as well as the comments and feedback provided by experts in MIS during the subjective validation study. Finally, the process was iterative, in that a process of analysis, design, evaluation, and redesign was applied (Table 1) until a good enough protocol was obtained that could be subjected to validation studies [129].

To develop this study's 3D virtual environment, the researchers adopted the principle of low fidelity, given that the model is envisaged for basic psychomotor skills learning. The term fidelity refers to the extent to which a simulation imitates reality (in the case of surgical simulation, the anatomy) and is considered a critical variable in the design of simulators.
However, this statement is not necessarily completely true, as for novice learners, low-fidelity models that reproduce the essential constructs of a procedure allow a faster and more cost-effective learning curve to be achieved $[35,130]$. Thus, in the field of simulation in aviation, simple images reduce the learner's confusion when learning basic skills [131], while experts benefit from higher fidelity simulations [33,132].

The tasks were adapted from the MIST-VR, which is the only laparoscopic VR trainer that can act as a standard because it is the sole surgical VR system that has been reasonably validated $[4,11,65,133]$. MIST-VR has been shown to allow the learning of basic skills that can be transferred to the surgical environment at a more reasonable cost $[4,11,52,73,134]$.

\section{Metrics}

Performance evaluation is a fundamental part of the learning process and is essential for certification. To obtain an objective evaluation of performance, the simulator should define metrics that must be valid, accurate, and relevant in terms of the procedure that is being taught. Evaluation using metrics and effective feedback are the most important elements of effective learning in a simulation environment [7]. Metrics allow an objective measure of motor performance to be obtained and enable the learning progress to be compared and tracked $[10,43,44]$. Accordingly, if the metrics lack sensitivity and validity, training on simulators will not be optimal and the learning will be affected [135]. In SIMISGEST-VR, the metrics were determined by time, the efficiency of movement, economy of diathermy, and error. This was an iterative process involving several pilot studies and modifications to the tasks and their metrics based on feedback provided by surgeons and education experts.

\section{Feedback}

Feedback is essential $[136,137]$. Training on a simulator should have 3 purposes: (1) to improve performance; (2) to make the performance consistent; and (3) to reduce the number of errors [57]. The metrics and feedback are essential for achieving these objectives. On the SIMISGEST-VR, the study adopted 3 types of feedback: (1) concurrent, which is provided while the task is being performed; (2) immediate, when the exercise is finished; and (3) terminal, which shows the final score when all the tasks have been completed [136,138-140]. 


\section{Hardware}

The design of the hardware components aimed to simulate the movements made by the surgeon during MIS. These movements are defined by the physical characteristics of the devices and, therefore, require the design of mechanical support devices that simulate the fulcrum effect (entry portals), add friction to the movements of the forceps, and limit arm movement during the performance of the tasks without interfering with the reading of the instrument movements by the LMC [141,142]. The portability and low cost were also taken into account.

\section{Cost of Gesture-Mediated Simulator for Minimally Invasive Surgery-Virtual Reality}

The VR or augmented VR simulators currently available in the market are not portable, and their cost ranges from US \$2000 to US $\$ 100,000$ (with annual maintenance costs of US $\$ 25,000$ ) for a haptic VR simulator. The LMC costs approximately US $\$ 130$, plus a further US $\$ 70$ for the hardware elements, adding up to a total cost of approximately US $\$ 200$ for the SIMISGEST-VR, software costs excluded.

\section{Subjective Validation of Gesture-Mediated Simulator for Minimally Invasive Surgery-Virtual Reality}

The second aim of this study was to evaluate fidelity to the criterion and a content validity study. Validity refers to the quality of the inferences, claims, or decisions taken from the scores given by an instrument, not the instrument itself. Validation for its part is a process through which the evidence that supports the quality, significance, and utility of the decisions and inferences that can be made from the scores provided by the instrument is drawn together and evaluated [143]. Validity is not an all-or-nothing statement, as it reflects a gradual appraisal that depends on the purpose of the measurement and the proper interpretation of the results. Validity is also not in itself a characteristic of the system, but the appropriate interpretation and use of the measurement results of the system. A single instrument may be used for many different purposes, and the resulting scores may be more valid for one purpose than for another [133].

\section{Study of Fidelity to Criterion}

Although it has been deemed that face validity should no longer be considered a type of validity or used as a term in validation studies [144,145], its assessment is extremely important during the design phase of any evaluation device [146,147]. Therefore, the use of an alternative term to denominate this type of evaluation has been suggested: fidelity to the criterion [148]. Despite such warnings, it is very striking to find that the term face validity is still being used in published literature on simulation in surgery $[149,150]$.

Fidelity to the criterion evaluates to what point the test reflects the real-life situation, whether the simulator represents what it is supposed to represent (the realism of the simulator) or the extent to which a questionnaire or other measurement reflects the variable to be measured $[125,151,152]$. In the case of DBR, it is used in the initial phase of the construction of the test. The surveys that assess fidelity to the criterion feedback into the iterative design process, which allows the good enough prototype to be obtained [153]. Fidelity to the criterion is evaluated by experts and novices called referents $[154,155]$.

In this study, the evaluation of fidelity to the criterion provided feedback on the initial design, and this was how the 3D virtual environment was redesigned until a good enough prototype was obtained. The quality of this evaluation is improved systematically when structured questionnaires and Likert scales are applied [154].

In all the items evaluated for fidelity to the criterion, most of those surveyed assigned scores of 4 or 5 . There were no significant differences between the expert and referent groups (level of training) when rating fidelity to the criterion. The lowest scores were obtained for the item about the relevance ( $n=9 / 30,3 \%$ of participants), the representation of the movements of the physical forceps in the virtual environment $(n=9 / 30,3 \%)$, and for the fulcrum effect $(n=3 / 30,10 \%)$.

\section{Evidence Based on Test Content}

The latest standards on validity and validation refer to sources of validity evidence, rather than distinct types of validity. Validity therefore refers to the degree to which the evidence and theory support the interpretations of test scores for the proposed uses of tests $[156,157]$.

Evidence based on test content is an issue of representation and may be obtained from an analysis of the relationship between test content and the construct that is intended to be measured. In this study, the test content refers to the simulator's 6 specific tasks. Evidence can be obtained from logical or empirical analyses of how test content represents domain content and of the relevance of domain content to the proposed interpretation of test scores. Evidence may also come from experts' opinions on the relationship between the different test items and the construct when assessing whether the test contains the meaningful steps, skills, and materials used in the actual procedure [158] and determines whether the simulator can realistically teach what it is supposed to represent [159].

The question is, does the simulator realistically teach what it should teach? In other words, does the instrument represent all the ways in which it can be used to measure the content of a given construct? [160]. In summary, evidence based on test content judges the appropriateness of the simulator as a teaching modality or as a training tool within the domain that it seeks to measure [31,151,152].

This type of validation is highly recommended in the practice of DBR during the design phase of the good enough prototype. Content validity can be obtained from a literature review, an expert review, using content validity rates, and $Q$ sorting [161].

The tasks within the surgical simulation should fulfill 3 criteria: objectivity, clarity, and completeness. To be objective, the definition of the task should refer to observable characteristics of the behavior; for it to be clear, the task should be unambiguous so that it can be read, understood, and reproduced equally by different observers; and finally, to meet the criterion of completeness, the definition of the task should delineate its start and end and make it clear when it was completed [162]. 
In this study, the 6 skill tasks were chosen for two main reasons: (1) these tasks are well-validated in many clinical studies [4,10,82,117] using the MIST-VR (Table 6); and (2) they contain laparoscopic skills and techniques that are usually present in many laparoscopic procedures (Table 1).

The vast majority of study participants considered that the SIMISGEST-VR was a useful tool for the development of hand-eye coordination and depth perception, with ratings of 4 and 5 on the Likert scale. Similarly, there was consensus about the capacity of the simulator to teach basic psychomotor skills and to reflect the basic steps in MIS. All the respondents considered the metrics to be adequate and envisaged that the simulator could become a solution to achieve ubiquitous learning of basic psychomotor skills in MIS.

In terms of the specific rating for each of the 6 tasks, this varied between 3.97 and 4.53. The participants considered all the items of the SIMISGEST-VR training system as good to excellent.

Finally, the study of fidelity to the criterion and content validity must be proven in the design stage of the artifact, before the criterion (concurrent and predictive) and construct validity (convergent and discriminative) can be confirmed. The evaluation of fidelity to the criterion, although somewhat subjective, is a necessary assessment during the initial phase of any high-stakes test construction and in this study, within the context of DBR, in the design phase of prototypes that will give a good enough prototype as a result [154,158,163]. In conclusion, the results of the study of fidelity to the criterion and content-related validity evidence showed overall positive scores.

\section{Threats to Validity}

The Hawthorne effect occurs when the opinion may be influenced by the attention paid to the respondent during his or her performance with the simulator, which may contribute to the occurrence of favorable responses or scores. This effect can be ameliorated by paying equal attention to each respondent. In addition, the Pygmalion effect occurs when the enthusiasm shown by the developers or because the novelty of the artifact affects the opinion of the respondent; the referent group is more prone to this latter effect [154,164]. In this study, the SIMISGEST-VR developer conducted the interviews and applied the Likert scale questionnaires; this may have influenced the ratings assigned by the participants (Hawthorne effect).

Regarding the representation of the construct, in this study there was an underrepresentation-when compared with the learning models based on training boxes-referring to the cut skill of the basic psychomotor skills construct, which was because of technical reasons associated with the LMC (construct context). There was no overrepresentation of the construct [165].

\section{Limitations}

There are, however, limitations to this study. The sample size of this study was one of availability and, for the simulator to be portable and allow ubiquitous learning, the researchers disregarded some ergonomic principles applied to MIS $[166,167]$. Further research will be conducted using new motion metrics, new skill tasks, and the development of the web-based virtual environment for download as an app. In addition, the researchers of this study are working on the development of different difficulty levels for each exercise.

\section{Future Work}

The researchers of this study are currently conducting another study to show validity evidence for the good enough prototype described in this paper, using the new framework for validation in education $[168,169]$. This new study is expected to verify the sources of validity evidence for the internal structure, relationships between variables, and test consequences.

Once the metrics and the results of the performance scores have been validated as a useful tool for learning basic psychomotor skills in MIS, a model will be obtained to enable ubiquitous learning in MIS and preoperative warm-up by using the 3D reconstruction of patient images [14]. Studies conducted in this area have demonstrated that, generally speaking, preoperative warm-up exercises performed for at least $15 \mathrm{~min}$ before the procedure improve the surgeon's handling of soft tissue during cholecystectomy [170], bimanual skill, efficiency and smoothness of movement, and depth perception, at the same time as mistakes and operating time are reduced [171-177].

The large size and elevated costs of VR simulators currently available in the market prohibit their use in the operating theater. A portable, low-cost simulation solution, such as the SIMISGEST-VR, would allow surgeons to perform preoperative warm-up exercises anytime, anywhere (ubiquitous learning). In addition, the researchers aim to enable a surgeon to perform warm-up exercises based on 3D reconstructions of preoperative images of a specific patient, thus, practicing the procedure before performing the actual surgery. This could take place the night before in the surgeon's home or the operating theater on the day of the surgery [178-183]

\section{Conclusions}

This study demonstrated the feasibility of a portable, low-cost, gesture-based, functional simulator (SIMISGEST-VR) for learning basic psychomotor skills in MIS.

The results of the evaluation of fidelity to the criterion and content validity showed overall positive scores, which indicates that the SIMISGEST-VR would be acceptable to both the expert group and referent group as a training and learning device (including at home) to achieve ubiquitous learning in MIS.

The participants in the study agreed that content validity was acceptable, accurate, and representative in the field of basic psychomotor skills learning in MIS. 


\section{Authors' Contributions}

All the authors contributed substantially to the study conception and design, data analysis, and interpretation of the findings and manuscript drafting. Fernando Álvarez López participated in the collection and assembly of data. Francesc Saigí-Rubió is the guarantor of the paper. All the authors have read, revised, and approved the final manuscript.

\section{Conflicts of Interest}

None declared.

\section{Multimedia Appendix 1}

Application forms of the demographic survey, fidelity to the criterion, and content validity surveys.

[DOCX File, $20 \mathrm{~KB}-$ Multimedia Appendix 1]

\section{Multimedia Appendix 2}

Results of the fidelity to the criterion survey.

[DOCX File , 26 KB-Multimedia Appendix 2]

\section{Multimedia Appendix 3}

Results of the content validity survey.

[DOCX File, 38 KB-Multimedia Appendix 3]

\section{References}

1. Litynski GS. Profiles in laparoscopy: Mouret, Dubois, and Perissat: the laparoscopic breakthrough in Europe (1987-1988). JSLS-J Soc Laparoend 1999;3(2):163-167 [FREE Full text] [Medline: 10444020]

2. Yamashita Y, Kurohiji T, Kakegawa T. Evaluation of two training programs for laparoscopic cholecystectomy: incidence of major complications. World J Surg 1994;18(2):279-85; discussion 285. [doi: 10.1007/BF00294415] [Medline: 8042335]

3. Wolfe BM, Gardiner B, Frey CF. Laparoscopic cholecystectomy: a remarkable development. J Am Med Assoc 2015 Oct 6;314(13):1406. [doi: 10.1001/jama.2014.12014] [Medline: 26441196]

4. Seymour NE, Gallagher AG, Roman SA, O'Brien MK, Bansal VK, Andersen DK, et al. Virtual reality training improves operating room performance: results of a randomized, double-blinded study. Ann Surg 2002 Oct;236(4):458-63; discussion 463. [doi: 10.1097/00000658-200210000-00008] [Medline: 12368674 ]

5. Dawe SR, Pena GN, Windsor JA, Broeders JA, Cregan PC, Hewett PJ, et al. Systematic review of skills transfer after surgical simulation-based training. Br J Surg 2014 Aug;101(9):1063-1076. [doi: 10.1002/bjs.9482] [Medline: 24827930]

6. Botden SM, Jakimowicz JJ. What is going on in augmented reality simulation in laparoscopic surgery? Surg Endosc 2009 Aug;23(8):1693-1700 [FREE Full text] [doi: 10.1007/s00464-008-0144-1] [Medline: 18813987]

7. Papanikolaou I. Assessment of medical simulators as a training programme for current surgical education. Hellenic J Surg 2013 Aug 9;85(4):240-248 [FREE Full text] [doi: 10.1007/s13126-013-0047-z]

8. Escamirosa FP, Flores RM, García IG, Vidal CR, Martínez AM. Face, content, and construct validity of the EndoViS training system for objective assessment of psychomotor skills of laparoscopic surgeons. Surg Endosc 2015 Nov;29(11):3392-3403. [doi: 10.1007/s00464-014-4032-6] [Medline: 25515985]

9. Sutton C, McCloy R, Middlebrook A, Chater P, Wilson M, Stone R. MIST VR. A laparoscopic surgery procedures trainer and evaluator. Stud Health Technol Inform 1997;39:598-607. [Medline: 10173070]

10. Taffinder N, Sutton C, Fishwick RJ, McManus IC, Darzi A. Validation of virtual reality to teach and assess psychomotor skills in laparoscopic surgery: results from randomised controlled studies using the MIST VR laparoscopic simulator. Stud Health Technol Inform 1998;50:124-130. [Medline: 10180527]

11. Ahlberg G, Heikkinen T, Iselius L, Leijonmarck C, Rutqvist J, Arvidsson D. Does training in a virtual reality simulator improve surgical performance? Surg Endosc 2002 Jan;16(1):126-129. [doi: 10.1007/s00464-001-9025-6] [Medline: $\underline{11961622]}$

12. Debes AJ, Aggarwal R, Balasundaram I, Jacobsen MB. A tale of two trainers: virtual reality versus a video trainer for acquisition of basic laparoscopic skills. Am J Surg 2010 Jun;199(6):840-845. [doi: 10.1016/j.amjsurg.2009.05.016] [Medline: 20079480]

13. Torkington J, Smith S, Rees B, Darzi A. Skill transfer from virtual reality to a real laparoscopic task. Surg Endosc 2001 Oct;15(10):1076-1079. [doi: 10.1007/s004640000233] [Medline: 11727073]

14. Alvarez-Lopez F, Maina MF, Saigí-Rubió F. Use of commercial off-the-shelf devices for the detection of manual gestures in surgery: systematic literature review. J Med Internet Res 2019 Apr 14;21(5):e11925 [FREE Full text] [doi: 10.2196/11925] [Medline: 31066679]

15. Simon H. The Sciences of the Artificial. Third Edition. Cambridge, MA: MIT Press; 1996. 
16. Manson N. Is operations research really research? ORiON 2006 Dec 1;22(2):-. [doi: 10.5784/22-2-40]

17. Hevner AR, March ST, Park J, Ram S. Design science in information systems research. MIS Q 2004;28(1):75. [doi: $\underline{10.2307 / 25148625]}$

18. March ST, Smith GF. Design and natural science research on information technology. Decis Support Syst 1995 Dec;15(4):251-266. [doi: 10.1016/0167-9236(94)00041-2]

19. Hevner A, Chatterjee S. Design Research in Information Systems: Theory and Practice. New York, USA: Springer; 2010.

20. Dresch A, Pacheco-Lacerda D, Valle-Antunes J. Design Science Research: A Method for Science and Technology Advancement. New York, USA: Springer; 2015.

21. Takeda H, Veerkamp P, Tomiyama T, Yoshikawa H. Modeling design processes. AI Mag 1980 Dec 15;11(4):48. [doi: 10.1609/aimag.v11i4.855]

22. Vaishnavi V, Kuechler B, Petter S. Design Science Research in Information Systems. DESRIST. 2017. URL: http://www. desrist.org/design-research-in-information-systems/ [accessed 2020-05-20]

23. Ogura T, Sato M, Ishida Y, Hayashi N, Doi K. Development of a novel method for manipulation of angiographic images by use of a motion sensor in operating rooms. Radiol Phys Technol 2014 Jul;7(2):228-234. [doi: 10.1007/s12194-014-0259-0] [Medline: 24609904]

24. Mauser S, Burgert O. Touch-free, gesture-based control of medical devices and software based on the leap motion controller. Stud Health Technol Inform 2014;196:265-270. [Medline: 24732520]

25. Bachmann D, Weichert F, Rinkenauer G. Evaluation of the leap motion controller as a new contact-free pointing device. Sensors (Basel) 2014 Dec 24;15(1):214-233 [FREE Full text] [doi: 10.3390/s150100214] [Medline: 25609043]

26. Weichert F, Bachmann D, Rudak B, Fisseler D. Analysis of the accuracy and robustness of the leap motion controller. Sensors (Basel) 2013 May 14;13(5):6380-6393 [FREE Full text] [doi: 10.3390/s130506380] [Medline: 23673678]

27. Guna J, Jakus G, Pogačnik M, Tomažič S, Sodnik J. An analysis of the precision and reliability of the leap motion sensor and its suitability for static and dynamic tracking. Sensors (Basel) 2014 Feb 21;14(2):3702-3720 [FREE Full text] [doi: 10.3390/s140203702] [Medline: 24566635]

28. Alvarez-Lopez F, Maina MF, Saigí-Rubió F. Natural user interfaces: is it a solution to accomplish ubiquitous training in minimally invasive surgery? Surg Innov 2016 Aug;23(4):429-430. [doi: 10.1177/1553350616639145] [Medline: 27009688]

29. Beck P. Accurate Three-dimensional Instrument Positioning. Google Patents. 2016. URL: https://patents.google.com/patent/ US9918798B2/en [accessed 2020-05-29]

30. Takiyama K, Shinya M. Development of a portable motor learning laboratory (PoMLab). PLoS One 2016;11(6):e0157588 [FREE Full text] [doi: 10.1371/journal.pone.0157588] [Medline: 27348223]

31. Moorthy K, Munz Y, Sarker SK, Darzi A. Objective assessment of technical skills in surgery. Br Med J 2003 Nov 1;327(7422):1032-1037 [FREE Full text] [doi: 10.1136/bmj.327.7422.1032] [Medline: 14593041]

32. Mccloy R, Wilson M, Sutton C, Middlebrook A, Chater P, Stone R. MIST VR: apart-task virtual reality trainer for laparoscopic surgery. J Telemed Telecare 2016 Dec 2;3(1_Suppl):97. [doi: 10.1258/1357633971930652]

33. Seymour NE, Røtnes JS. Challenges to the development of complex virtual reality surgical simulations. Surg Endosc 2006 Nov;20(11):1774-1777. [doi: 10.1007/s00464-006-0107-3] [Medline: 16960667]

34. Carter FJ, Schijven MP, Aggarwal R, Grantcharov T, Francis NK, Hanna GB, Work Group for Evaluation and Implementation of Simulators and Skills Training Programmes. Consensus guidelines for validation of virtual reality surgical simulators. Surg Endosc 2005 Dec;19(12):1523-1532. [doi: 10.1007/s00464-005-0384-2] [Medline: 16252077]

35. Alessi S. Fidelity in the design of instructional simulations. J Comput Based Instr 1988;15(2):7. [doi: 10.5555/46756.46757]

36. Stone RJ. The (human) science of medical virtual learning environments. Philos Trans R Soc Lond B Biol Sci 2011 Jan 27;366(1562):276-285 [FREE Full text] [doi: 10.1098/rstb.2010.0209] [Medline: 21149363]

37. Kothari SN, Kaplan BJ, DeMaria EJ, Broderick TJ, Merrell RC. Training in laparoscopic suturing skills using a new computer-based virtual reality simulator (MIST-VR) provides results comparable to those with an established pelvic trainer system. J Laparoendosc Adv Surg Tech A 2002 Jun;12(3):167-173. [doi: 10.1089/10926420260188056] [Medline: 12184901]

38. Schijven M, Jakimowicz J. Virtual reality surgical laparoscopic simulators. Surg Endosc 2003 Dec;17(12):1943-1950. [doi: 10.1007/s00464-003-9052-6] [Medline: 14574546]

39. Bowman DA, Chen J, Wingrave CA, Lucas J, Ray A, Polys NF, et al. New directions in 3D user interfaces. Int J Virtual Real 2006 Jan 1;5(2):3-14. [doi: 10.20870/ijvr.2006.5.2.2683]

40. Schout BM, Hendrikx AJ, Scheele F, Bemelmans BL, Scherpbier AJ. Validation and implementation of surgical simulators: a critical review of present, past, and future. Surg Endosc 2010 Mar;24(3):536-546 [FREE Full text] [doi:

10.1007/s00464-009-0634-9] [Medline: 19633886]

41. Ali M, Mowery Y, Kaplan B, DeMaria E. Training the novice in laparoscopy. More challenge is better. Surg Endosc 2002 Dec;16(12):1732-1736. [doi: 10.1007/s00464-002-8850-6] [Medline: 12140638]

42. Sullivan K, Kantak S, Burtner P. Motor learning in children: feedback effects on skill acquisition. Phys Ther 2008 Jun;88(6):720-732. [doi: 10.2522/ptj.20070196] [Medline: 18339797]

43. Chaudhry A, Sutton C, Wood J, Stone R, McCloy R. Learning rate for laparoscopic surgical skills on MIST VR, a virtual reality simulator: quality of human-computer interface. Ann R Coll Surg Engl 1999 Jul;81(4):281-286 [FREE Full text] [Medline: $\underline{10615201]}$ 
44. Stylopoulos N, Vosburgh KG. Assessing technical skill in surgery and endoscopy: a set of metrics and an algorithm (C-PASS) to assess skills in surgical and endoscopic procedures. Surg Innov 2007 Jun;14(2):113-121. [doi: 10.1177/1553350607302330] [Medline: 17558017]

45. Oropesa I, de Jong T, Sánchez-González P, Dankelman J, Gómez E. Feasibility of tracking laparoscopic instruments in a box trainer using a leap motion controller. Measurement 2016 Feb;80:115-124. [doi: 10.1016/j.measurement.2015.11.018]

46. Wilson MS, Middlebrook A, Sutton C, Stone R, McCloy RF. MIST VR: a virtual reality trainer for laparoscopic surgery assesses performance. Ann R Coll Surg Engl 1997 Nov;79(6):403-404 [FREE Full text] [Medline: 9422863]

47. Grantcharov TP, Bardram L, Funch-Jensen P, Rosenberg J. Learning curves and impact of previous operative experience on performance on a virtual reality simulator to test laparoscopic surgical skills. Am J Surg 2003 Feb;185(2):146-149. [doi: 10.1016/s0002-9610(02)01213-8] [Medline: 12559445]

48. Maithel S, Sierra R, Korndorffer J, Neumann P, Dawson S, Callery M, et al. Construct and face validity of MIST-VR, endotower, and CELTS: are we ready for skills assessment using simulators? Surg Endosc 2006 Jan;20(1):104-112. [doi: 10.1007/s00464-005-0054-4] [Medline: 16333535]

49. Aggarwal R, Grantcharov T, Moorthy K, Hance J, Darzi A. A competency-based virtual reality training curriculum for the acquisition of laparoscopic psychomotor skill. Am J Surg 2006 Jan;191(1):128-133. [doi: 10.1016/j.amjsurg.2005.10.014] [Medline: 16399123$]$

50. van Sickle KR, Ritter EM, McClusky DA, Lederman A, Baghai M, Gallagher AG, et al. Attempted establishment of proficiency levels for laparoscopic performance on a national scale using simulation: the results from the 2004 SAGES minimally invasive surgical trainer-virtual reality (MIST-VR) learning center study. Surg Endosc 2007 Jan;21(1):5-10. [doi: $10.1007 / \mathrm{s} 00464-006-0011-\mathrm{x}]$ [Medline: $\underline{17111280}$ ]

51. Munz Y, Almoudaris AM, Moorthy K, Dosis A, Liddle AD, Darzi AW. Curriculum-based solo virtual reality training for laparoscopic intracorporeal knot tying: objective assessment of the transfer of skill from virtual reality to reality. Am J Surg 2007 Jun;193(6):774-783. [doi: 10.1016/j.amjsurg.2007.01.022] [Medline: 17512295]

52. Grantcharov TP, Rosenberg J, Pahle E, Funch-Jensen P. Virtual reality computer simulation. Surg Endosc 2001 Mar;15(3):242-244. [doi: 10.1007/s004640090008] [Medline: 11344422]

53. Paisley AM, Baldwin PJ, Paterson-Brown S. Validity of surgical simulation for the assessment of operative skill. Br J Surg 2001 Nov;88(11):1525-1532. [doi: 10.1046/j.0007-1323.2001.01880.x] [Medline: 11683753]

54. Torkington J, Smith S, Rees B, Darzi A. The role of the basic surgical skills course in the acquisition and retention of laparoscopic skill. Surg Endosc 2001 Oct;15(10):1071-1075. [doi: 10.1007/s004640000183] [Medline: 11727072]

55. Gallagher AG, Richie K, McClure N, McGuigan J. Objective psychomotor skills assessment of experienced, junior, and novice laparoscopists with virtual reality. World J Surg 2001 Nov;25(11):1478-1483. [doi: 10.1007/s00268-001-0133-1] [Medline: 11760752]

56. Pearson A, Gallagher A, Rosser J, Satava R. Evaluation of structured and quantitative training methods for teaching intracorporeal knot tying. Surg Endosc 2002 Jan;16(1):130-137. [doi: 10.1007/s00464-001-8113-y] [Medline: 11961623]

57. Gallagher A, Satava R. Virtual reality as a metric for the assessment of laparoscopic psychomotor skills. Learning curves and reliability measures. Surg Endosc 2002 Dec;16(12):1746-1752. [doi: 10.1007/s00464-001-8215-6] [Medline: 12140641]

58. Kozlowski S, de Shon R. Scaled Worlds: development, validation, and applications. In: Inalas E, Elliott LR, Schflett SG, Coovert MD, editors. A Psychological Fidelity Approach to Simulation-based Training: Theory, Research, and Principles. Burlington, VT: Ashgate Publishing; 2004.

59. Gor M, McCloy R, Stone R, Smith A. Virtual reality laparoscopic simulator for assessment in gynaecology. BJOG 2003 Feb;110(2):181-187 [FREE Full text] [Medline: 12618163]

60. Gallagher AG, Smith CD, Bowers SP, Seymour NE, Pearson A, McNatt S, et al. Psychomotor skills assessment in practicing surgeons experienced in performing advanced laparoscopic procedures. J Am Coll Surg 2003 Sep;197(3):479-488. [doi: 10.1016/S1072-7515(03)00535-0] [Medline: 12946803]

61. Mackay S, Datta V, Chang A, Shah J, Kneebone R, Darzi A. Multiple objective measures of skill (MOMS): a new approach to the assessment of technical ability in surgical trainees. Ann Surg 2003 Aug;238(2):291-300. [doi: 10.1097/01.sla.0000080829.29028.c4] [Medline: 12894024$]$

62. Stefanidis D, Korndorffer JR, Sierra R, Touchard C, Dunne JB, Scott DJ. Skill retention following proficiency-based laparoscopic simulator training. Surgery 2005 Aug;138(2):165-170. [doi: 10.1016/j.surg.2005.06.002] [Medline: 16153423]

63. Gallagher A, Satava R. Virtual reality as a metric for the assessment of laparoscopic psychomotor skills. Learning curves and reliability measures. Surg Endosc 2002 Dec;16(12):1746-1752. [doi: 10.1007/s00464-001-8215-6] [Medline: 12140641]

64. Taffinder N, McManus I, Gul Y, Russell R, Darzi A. Effect of sleep deprivation on surgeons' dexterity on laparoscopy simulator. Lancet 1998 Oct 10;352(9135):1191. [doi: 10.1016/s0140-6736(98)00034-8] [Medline: 9777838]

65. Taffinder N, Sutton C, Fishwick RJ, McManus IC, Darzi A. Validation of virtual reality to teach and assess psychomotor skills in laparoscopic surgery: results from randomised controlled studies using the MIST VR laparoscopic simulator. Stud Health Technol Inform 1998;50:124-130. [Medline: 10180527]

66. Jordan J, Gallagher AG, McGuigan J, McGlade K, McClure N. A comparison between randomly alternating imaging, normal laparoscopic imaging, and virtual reality training in laparoscopic psychomotor skill acquisition. Am J Surg 2000 Sep;180(3):208-211. [doi: 10.1016/s0002-9610(00)00469-4] [Medline: 11084131] 
67. Gallagher AG, Hughes C, Reinhardt-Rutland AH, McGuigan J, McClure N. A case-control comparison of traditional and virtual-reality training in laparoscopic psychomotor performance. Minim Invasive Ther Allied Technol 2009 Jul 10;9(5):347-352. [doi: 10.3109/13645700009061457]

68. Jordan JA, Gallagher AG, McGuigan J, McClure N. Randomly alternating image presentation during laparoscopic training leads to faster automation to the 'fulcrum effect'. Endoscopy 2000 Apr;32(4):317-321. [doi: 10.1055/s-2000-7374] [Medline: 10774973]

69. Jordan J, Gallagher A, McGuigan J, McClure N. Virtual reality training leads to faster adaptation to the novel psychomotor restrictions encountered by laparoscopic surgeons. Surg Endosc 2001 Oct;15(10):1080-1084. [doi: 10.1007/s004640000374] [Medline: 11727074$]$

70. McNatt S, Smith C. A computer-based laparoscopic skills assessment device differentiates experienced from novice laparoscopic surgeons. Surg Endosc 2001 Oct;15(10):1085-1089. [doi: 10.1007/s004640080022] [Medline: 11727075]

71. Gallagher H, Allan J, Tolley D. Spatial awareness in urologists: are they different? BJU Int 2001 Nov;88(7):666-670 [FREE Full text] [doi: $10.1046 / j .1464-4096.2001 .02440 . x$ ] [Medline: 11890233 ]

72. Grantcharov TP, Bardram L, Funch-Jensen P, Rosenberg J. Laparoscopic performance after one night on call in a surgical department: prospective study. Br Med J 2001 Nov 24;323(7323):1222-1223 [FREE Full text] [doi: 10.1136/bmj.323.7323.1222] [Medline: 11719413 ]

73. Hamilton E, Scott D, Fleming J, Rege R, Laycock R, Bergen P, et al. Comparison of video trainer and virtual reality training systems on acquisition of laparoscopic skills. Surg Endosc 2002 Mar;16(3):406-411. [doi: 10.1007/s00464-001-8149-z] [Medline: 11928017]

74. Grantcharov TP, Bardram L, Funch-Jensen P, Rosenberg J. Impact of hand dominance, gender, and experience with computer games on performance in virtual reality laparoscopy. Surg Endosc 2003 Jul;17(7):1082-1085. [doi: 10.1007/s00464-002-9176-0] [Medline: 12728373]

75. Eastridge BJ, Hamilton EC, O'Keefe GE, Rege RV, Valentine RJ, Jones DJ, et al. Effect of sleep deprivation on the performance of simulated laparoscopic surgical skill. Am J Surg 2003 Aug;186(2):169-174. [doi: 10.1016/s0002-9610(03)00183-1] [Medline: 12885613]

76. Madan AK, Frantzides CT, Shervin N, Tebbit CL. Assessment of individual hand performance in box trainers compared to virtual reality trainers. Am Surg 2003 Dec;69(12):1112-1114. [Medline: 14700302]

77. Bann S, Kwok K, Lo C, Darzi A, Wong J. Objective assessment of technical skills of surgical trainees in Hong Kong. Br J Surg 2003 Oct;90(10):1294-1299. [doi: 10.1002/bjs.4222] [Medline: 14515303]

78. Gonzalez R, Bowers SP, Smith CD, Ramshaw BJ. Does setting specific goals and providing feedback during training result in better acquisition of laparoscopic skills? Am Surg 2004 Jan;70(1):35-39. [Medline: 14964544]

79. Gallagher AG, Lederman AB, McGlade K, Satava RM, Smith CD. Discriminative validity of the minimally invasive surgical trainer in virtual reality (MIST-VR) using criteria levels based on expert performance. Surg Endosc 2004 Apr;18(4):660-665. [doi: 10.1007/s00464-003-8176-z] [Medline: 15026925]

80. Fried MP, Satava R, Weghorst S, Gallagher AG, Sasaki C, Ross D, et al. Identifying and reducing errors with surgical simulation. Qual Saf Health Care 2004 Oct;13(Suppl 1):i19-i26 [FREE Full text] [doi: 10.1136/qhc.13.suppl 1.i19] [Medline: 15465950]

81. Ström P, Kjellin A, Hedman L, Wredmark T, Felländer-Tsai L. Training in tasks with different visual-spatial components does not improve virtual arthroscopy performance. Surg Endosc 2004 Jan;18(1):115-120. [doi: 10.1007/s00464-003-9023-y] [Medline: 14625735$]$

82. Uchal M, Raftopoulos Y, Tjugum J, Bergamaschi R. Validation of a six-task simulation model in minimally invasive surgery. Surg Endosc 2005 Jan;19(1):109-116. [doi: 10.1007/s00464-004-8145-1] [Medline: 15531971]

83. Adamsen S, Funch-Jensen PM, Drewes AM, Rosenberg J, Grantcharov TP. A comparative study of skills in virtual laparoscopy and endoscopy. Surg Endosc 2005 Feb;19(2):229-234. [doi: 10.1007/s00464-004-9090-8] [Medline: 15580316]

84. Avgerinos DV, Goodell KH, Waxberg S, Cao CG, Schwaitzberg SD. Comparison of the sensitivity of physical and virtual laparoscopic surgical training simulators to the user's level of experience. Surg Endosc 2005 Sep;19(9):1211-1215. [doi: 10.1007/s00464-004-8256-8] [Medline: 16132320 ]

85. Huang J, Payandeh S, Doris P, Hajshirmohammadi I. Fuzzy classification: towards evaluating performance on a surgical simulator. Stud Health Technol Inform 2005;111:194-200. [Medline: 15718726]

86. Madan AK, Frantzides CT, Tebbit C, Quiros RM. Participants' opinions of laparoscopic training devices after a basic laparoscopic training course. Am J Surg 2005 Jun;189(6):758-761. [doi: 10.1016/j.amjsurg.2005.03.022] [Medline: 15910733]

87. McClusky DA, Ritter EM, Lederman AB, Gallagher AG, Smith CD. Correlation between perceptual, visuo-spatial, and psychomotor aptitude to duration of training required to reach performance goals on the MIST-VR surgical simulator. Am Surg 2005 Jan;71(1):13-20; discussion 20. [Medline: 15757051]

88. Arora H, Uribe J, Ralph W, Zeltsan M, Cuellar H, Gallagher A, et al. Assessment of construct validity of the endoscopic sinus surgery simulator. Arch Otolaryngol Head Neck Surg 2005 Mar;131(3):217-221. [doi: 10.1001/archotol.131.3.217] [Medline: 15781761] 
89. Uchal M, Tjugum J, Martinsen E, Qiu X, Bergamaschi R. The impact of sleep deprivation on product quality and procedure effectiveness in a laparoscopic physical simulator: a randomized controlled trial. Am J Surg 2005 Jun;189(6):753-757. [doi: 10.1016/j.amjsurg.2005.03.021] [Medline: 15910732]

90. Takiguchi S, Sekimoto M, Yasui M, Miyata H, Fujiwara Y, Yasuda T, et al. Cyber visual training as a new method for the mastery of endoscopic surgery. Surg Endosc 2005 Sep;19(9):1204-1210. [doi: 10.1007/s00464-004-8236-z] [Medline: 15942808]

91. DeMaria EJ, McBride CL, Broderick TJ, Kaplan BJ. Night call does not impair learning of laparoscopic skills. Surg Innov 2005 Jun;12(2):145-149. [doi: 10.1177/155335060501200213] [Medline: 16034504]

92. Hackethal A, Immenroth M, Bürger T. Evaluation of target scores and benchmarks for the traversal task scenario of the minimally invasive surgical trainer-virtual reality (MIST-VR) laparoscopy simulator. Surg Endosc 2006 Apr;20(4):645-650. [doi: 10.1007/s00464-004-2224-1] [Medline: 16424991]

93. Ström P, Hedman L, Särnå L, Kjellin A, Wredmark T, Felländer-Tsai L. Early exposure to haptic feedback enhances performance in surgical simulator training: a prospective randomized crossover study in surgical residents. Surg Endosc 2006 Sep;20(9):1383-1388. [doi: 10.1007/s00464-005-0545-3] [Medline: 16823652]

94. Goodell KH, Cao CG, Schwaitzberg SD. Effects of cognitive distraction on performance of laparoscopic surgical tasks. J Laparoendosc Adv Surg Tech A 2006 Apr;16(2):94-98. [doi: 10.1089/lap.2006.16.94] [Medline: 16646695]

95. Hedman L, Ström P, Andersson P, Kjellin A, Wredmark T, Felländer-Tsai L. High-level visual-spatial ability for novices correlates with performance in a visual-spatial complex surgical simulator task. Surg Endosc 2006 Aug;20(8):1275-1280. [doi: 10.1007/s00464-005-0036-6] [Medline: 16865624]

96. Hedman L, Klingberg T, Enochsson L, Kjellin A, Felländer-Tsai L. Visual working memory influences the performance in virtual image-guided surgical intervention. Surg Endosc 2007 Nov;21(11):2044-2050. [doi: 10.1007/s00464-007-9287-8] [Medline: 17522939]

97. Madan AK, Frantzides CT. Substituting virtual reality trainers for inanimate box trainers does not decrease laparoscopic skills acquisition. JSLS 2007;11(1):87-89 [FREE Full text] [Medline: 17651563]

98. Tanoue K, Ieiri S, Konishi K, Yasunaga T, Okazaki K, Yamaguchi S, et al. Effectiveness of endoscopic surgery training for medical students using a virtual reality simulator versus a box trainer: a randomized controlled trial. Surg Endosc 2008 Apr;22(4):985-990. [doi: 10.1007/s00464-007-9554-8] [Medline: 17710487]

99. Shane MD, Pettitt BJ, Morgenthal CB, Smith CD. Should surgical novices trade their retractors for joysticks? Videogame experience decreases the time needed to acquire surgical skills. Surg Endosc 2008 May;22(5):1294-1297. [doi: 10.1007/s00464-007-9614-0] [Medline: 17972136]

100. Schlickum MK, Hedman L, Enochsson L, Kjellin A, Felländer-Tsai L. Transfer of systematic computer game training in surgical novices on performance in virtual reality image guided surgical simulators. Stud Health Technol Inform 2008;132:210-215. [Medline: 18391288$]$

101. Windsor JA, Diener S, Zoha F. Learning style and laparoscopic experience in psychomotor skill performance using a virtual reality surgical simulator. Am J Surg 2008 Jun;195(6):837-842. [doi: 10.1016/j.amjsurg.2007.09.034] [Medline: 18417084]

102. Goldberg AE, Neifeld JP, Wolfe LG, Goldberg SR. Correlation of manual dexterity with USMLE scores and medical student class rank. J Surg Res 2008 Jun 15;147(2):212-215. [doi: 10.1016/j.jss.2008.02.050] [Medline: 18498872]

103. Botden SM, de Hingh IH, Jakimowicz JJ. Suturing training in augmented reality: gaining proficiency in suturing skills faster. Surg Endosc 2009 Sep;23(9):2131-2137 [FREE Full text] [doi: 10.1007/s00464-008-0240-2] [Medline: 19067051]

104. Grantcharov TP, Funch-Jensen P. Can everyone achieve proficiency with the laparoscopic technique? Learning curve patterns in technical skills acquisition. Am J Surg 2009 Apr;197(4):447-449. [doi: 10.1016/j.amjsurg.2008.01.024] [Medline: 19217604]

105. Schlickum MK, Hedman L, Enochsson L, Kjellin A, Felländer-Tsai L. Systematic video game training in surgical novices improves performance in virtual reality endoscopic surgical simulators: a prospective randomized study. World J Surg 2009 Nov;33(11):2360-2367. [doi: 10.1007/s00268-009-0151-y] [Medline: 19649553]

106. Moore A, Grow D, Bush R, Seymour N. Novices outperform experienced laparoscopists on virtual reality laparoscopy simulator. JSLS 2008;12(4):358-362 [FREE Full text] [Medline: 19275848]

107. van Sickle KR, Ritter EM, Baghai M, Goldenberg AE, Huang I, Gallagher AG, et al. Prospective, randomized, double-blind trial of curriculum-based training for intracorporeal suturing and knot tying. J Am Coll Surg 2008 Oct;207(4):560-568. [doi: 10.1016/j.jamcollsurg.2008.05.007] [Medline: 18926460]

108. Kanumuri P, Ganai S, Wohaibi EM, Bush RW, Grow DR, Seymour NE. Virtual reality and computer-enhanced training devices equally improve laparoscopic surgical skill in novices. JSLS 2008;12(3):219-226 [FREE Full text] [Medline: $\underline{18765042]}$

109. Madan AK, Harper JL, Frantzides CT, Tichansky DS. Nonsurgical skills do not predict baseline scores in inanimate box or virtual-reality trainers. Surg Endosc 2008 Jul;22(7):1686-1689. [doi: 10.1007/s00464-007-9691-0] [Medline: 18071808]

110. Arora S, Sevdalis N, Aggarwal R, Sirimanna P, Darzi A, Kneebone R. Stress impairs psychomotor performance in novice laparoscopic surgeons. Surg Endosc 2010 Oct;24(10):2588-2593. [doi: 10.1007/s00464-010-1013-2] [Medline: 20354878] 
111. Gallagher AG, Boyle E, Toner P, Neary PC, Andersen DK, Satava RM, et al. Persistent next-day effects of excessive alcohol consumption on laparoscopic surgical performance. Arch Surg 2011 Apr;146(4):419-426. [doi: 10.1001/archsurg.2011.67] [Medline: 21502449]

112. Zhou M, Tse S, Derevianko A, Jones DB, Schwaitzberg SD, Cao CG. Effect of haptic feedback in laparoscopic surgery skill acquisition. Surg Endosc 2012 Apr;26(4):1128-1134 [FREE Full text] [doi: 10.1007/s00464-011-2011-8] [Medline: 22044975]

113. Hedman L, Schlickum M, Felländer-Tsai L. Surgical novices randomized to train in two video games become more motivated during training in MIST-VR and GI Mentor II than students with no video game training. Stud Health Technol Inform 2013;184:189-194. [Medline: 23400154]

114. Gallagher AG, Seymour NE, Jordan-Black J, Bunting BP, McGlade K, Satava RM. Prospective, randomized assessment of transfer of training (ToT) and transfer effectiveness ratio (TER) of virtual reality simulation training for laparoscopic skill acquisition. Ann Surg 2013 Jun;257(6):1025-1031. [doi: 10.1097/SLA.0b013e318284f658] [Medline: 23426342]

115. Schlickum M, Hedman L, Felländer-Tsai L. Visual-spatial ability is more important than motivation for novices in surgical simulator training: a preliminary study. Int J Med Educ 2016 Feb 21;7:56-61 [FREE Full text] [doi: 10.5116/ijme.56b1.1691] [Medline: 26897701]

116. Oussi N, Loukas C, Kjellin A, Lahanas V, Georgiou K, Henningsohn L, et al. Video analysis in basic skills training: a way to expand the value and use of BlackBox training? Surg Endosc 2018 Jan;32(1):87-95 [FREE Full text] [doi: 10.1007/s00464-017-5641-7] [Medline: 28664435]

117. Gallagher AG, McClure N, McGuigan J, Crothers I, Browning J. Virtual reality training in laparoscopic surgery: a preliminary assessment of minimally invasive surgical trainer virtual reality (MIST VR). Endoscopy 1999 May;31(4):310-313. [doi: 10.1055/s-1999-15] [Medline: 10376458]

118. Mackay S, Morgan P, Datta V, Chang A, Darzi A. Practice distribution in procedural skills training: a randomized controlled trial. Surg Endosc 2002 Jun;16(6):957-961. [doi: 10.1007/s00464-001-9132-4] [Medline: 12163963]

119. Grantcharov TP, Kristiansen VB, Bendix J, Bardram L, Rosenberg J, Funch-Jensen P. Randomized clinical trial of virtual reality simulation for laparoscopic skills training. Br J Surg 2004 Feb;91(2):146-150. [doi: 10.1002/bjs.4407] [Medline: $\underline{14760660]}$

120. Brunner WC, Korndorffer JR, Sierra R, Massarweh NN, Dunne J, Yau C, et al. Laparoscopic virtual reality training: are 30 repetitions enough? J Surg Res 2004 Dec;122(2):150-156. [doi: 10.1016/j.jss.2004.08.006] [Medline: 15555611]

121. Brunner W, Korndorffer J, Sierra R, Dunne B, Yau L, Corsetti R, et al. Determining standards for laparoscopic proficiency using virtual reality. Am Surg 2005 Jan;71(1):29-35. [Medline: 15757053]

122. Madan AK, Frantzides CT, Sasso LM. Laparoscopic baseline ability assessment by virtual reality. J Laparoendosc Adv Surg Tech A 2005 Feb;15(1):13-17. [doi: 10.1089/lap.2005.15.13] [Medline: 15772470]

123. Schijven MP, Jakimowicz JJ, Broeders IA, Tseng LN. The Eindhoven laparoscopic cholecystectomy training course--improving operating room performance using virtual reality training: results from the first EAES accredited virtual reality trainings curriculum. Surg Endosc 2005 Sep;19(9):1220-1226. [doi: 10.1007/s00464-004-2240-1] [Medline: 16132332]

124. Barnes RW. Surgical handicraft: teaching and learning surgical skills. Am J Surg 1987 May;153(5):422-427. [doi: 10.1016/0002-9610(87)90783-5] [Medline: 3578661]

125. Karaliotas C. When simulation in surgical training meets virtual reality. Hellenic J Surg 2012 Feb 19;83(6):303-316. [doi: 10.1007/s13126-011-0055-9]

126. Sturm LP, Windsor JA, Cosman PH, Cregan P, Hewett PJ, Maddern GJ. A systematic review of skills transfer after surgical simulation training. Ann Surg 2008 Aug;248(2):166-179. [doi: 10.1097/SLA.0b013e318176bf24] [Medline: 18650625]

127. Sánchez-Margallo FM, Sánchez-Margallo JA, Moyano-Cuevas JL, Pérez EM, Maestre J. Use of natural user interfaces for image navigation during laparoscopic surgery: initial experience. Minim Invasive Ther Allied Technol 2017 Oct;26(5):253-261. [doi: 10.1080/13645706.2017.1304964] [Medline: 28349758]

128. Xu X, Zheng Y, Yao S, Sun G, Xu B, Chen X. A low-cost multimodal head-mounted display system for neuroendoscopic surgery. Brain Behav 2018 Jan 14;8(1):e00891 [FREE Full text] [doi: 10.1002/brb3.891] [Medline: 29568688]

129. Den AJ, Bannan B, Kelly A, Plomp T. SLO Netherlands institute for curriculum development part B: illustrative cases. In: Educational Design Research. New York, USA: Springer; 2013.

130. Lahanas V, Loukas C, Georgiou K, Lababidi H, Al-Jaroudi D. Virtual reality-based assessment of basic laparoscopic skills using the leap motion controller. Surg Endosc 2017 Dec;31(12):5012-5023. [doi: 10.1007/s00464-017-5503-3] [Medline: 28466361]

131. Noble C. The relationship between fidelity and learning in aviation training and assessment. J Air Transp 2002;7(3):33-54 [FREE Full text]

132. Park A, Witzke D. Training and educational approaches to minimally invasive surgery: state of the art. Semin Laparosc Surg 2002 Dec;9(4):198-205. [doi: 10.1053/slas.2002.36468] [Medline: 12522776]

133. Schijven M, Jakimowicz J. Construct validity: experts and novices performing on the Xitact LS500 laparoscopy simulator. Surg Endosc 2003 May;17(5):803-810. [doi: 10.1007/s00464-002-9151-9] [Medline: 12582752]

134. Badash I, Burtt K, Solorzano CA, Carey JN. Innovations in surgery simulation: a review of past, current and future techniques. Ann Transl Med 2016 Dec;4(23):453 [FREE Full text] [doi: 10.21037/atm.2016.12.24] [Medline: 28090509] 
135. Stefanidis D, Scott DJ, Korndorffer JR. Do metrics matter? Time versus motion tracking for performance assessment of proficiency-based laparoscopic skills training. Simul Healthc 2009;4(2):104-108. [doi: 10.1097/SIH.0b013e31819171ec] [Medline: 19444048]

136. Archer J. State of the science in health professional education: effective feedback. Med Educ 2010 Jan;44(1):101-108. [doi: 10.1111/j.1365-2923.2009.03546.x] [Medline: 20078761]

137. Cook DA, Brydges R, Zendejas B, Hamstra SJ, Hatala R. Technology-enhanced simulation to assess health professionals: a systematic review of validity evidence, research methods, and reporting quality. Acad Med 2013 Jun;88(6):872-883. [doi: 10.1097/ACM.0b013e31828ffdcf] [Medline: 23619073]

138. Hatala R, Cook DA, Zendejas B, Hamstra SJ, Brydges R. Feedback for simulation-based procedural skills training: a meta-analysis and critical narrative synthesis. Adv Health Sci Educ Theory Pract 2014 May;19(2):251-272. [doi: 10.1007/s10459-013-9462-8] [Medline: 23712700]

139. Walsh CM, Ling SC, Wang CS, Carnahan H. Concurrent versus terminal feedback: it may be better to wait. Acad Med 2009 Oct;84(10 Suppl):S54-S57. [doi: 10.1097/ACM.0b013e3181b38daf] [Medline: 19907387]

140. Stefanidis D, Korndorffer JR, Heniford BT, Scott DJ. Limited feedback and video tutorials optimize learning and resource utilization during laparoscopic simulator training. Surgery 2007 Aug;142(2):202-206. [doi: 10.1016/j.surg.2007.03.009] [Medline: 17689686$]$

141. Gallagher AG, McClure N, McGuigan J, Ritchie K, Sheehy NP. An ergonomic analysis of the fulcrum effect in the acquisition of endoscopic skills. Endoscopy 1998 Sep;30(7):617-620. [doi: 10.1055/s-2007-1001366] [Medline: 9826140]

142. Crothers IR, Gallagher AG, McClure N, James DT, McGuigan J. Experienced laparoscopic surgeons are automated to the 'fulcrum effect': an ergonomic demonstration. Endoscopy 1999 Jun;31(5):365-369. [doi: 10.1055/s-1999-26] [Medline: 10433045]

143. Chan E. Standards and guidelines for validation practices: development and evaluation of measurement instruments. In: Zumbo BD, Chan EK, editors. Validity and Validation in Social, Behavioral, and Health Sciences. New York, USA: Springer International Publishing; 2014.

144. Mosier CI. A critical examination of the concepts of face validity. Educ Psychol Meas 1947;7(2):191-205. [doi: 10.1177/001316444700700201] [Medline: 20256558]

145. Cook DA, Beckman TJ. Current concepts in validity and reliability for psychometric instruments: theory and application. Am J Med 2006 Feb;119(2):166.e7-166.16. [doi: 10.1016/j.amjmed.2005.10.036] [Medline: 16443422]

146. Sweet RM, Hananel D, Lawrenz F. A unified approach to validation, reliability, and education study design for surgical technical skills training. Arch Surg 2010 Feb;145(2):197-201. [doi: 10.1001/archsurg.2009.266] [Medline: 20157089]

147. Broe D, Ridgway PF, Johnson S, Tierney S, Conlon KC. Construct validation of a novel hybrid surgical simulator. Surg Endosc 2006 Jun;20(6):900-904. [doi: 10.1007/s00464-005-0530-x] [Medline: 16738979]

148. Downing SM. Face validity of assessments: faith-based interpretations or evidence-based science? Med Educ 2006 Jan;40(1):7-8. [doi: 10.1111/j.1365-2929.2005.02361.x] [Medline: 16441314]

149. Rod J, Marret J, Kohaut J, Aigrain Y, Jais JP, de Vries P, et al. Low-cost training simulator for open dismembered pyeloplasty: development and face validation. J Surg Educ 2018;75(1):188-194. [doi: 10.1016/j.jsurg.2017.06.010] [Medline: 28778782]

150. Leijte E, Arts E, Witteman B, Jakimowicz J, de Blaauw I, Botden S. Construct, content and face validity of the eoSim laparoscopic simulator on advanced suturing tasks. Surg Endosc 2019 Nov;33(11):3635-3643 [FREE Full text] [doi: 10.1007/s00464-018-06652-3] [Medline: 30671668]

151. Wanzel KR, Ward M, Reznick RK. Teaching the surgical craft: from selection to certification. Curr Probl Surg 2002 Jun;39(6):573-659. [doi: 10.1067/mog.2002.123481] [Medline: 12037512]

152. Gallagher AG, Ritter EM, Satava RM. Fundamental principles of validation, and reliability: rigorous science for the assessment of surgical education and training. Surg Endosc 2003 Oct;17(10):1525-1529. [doi: 10.1007/s00464-003-0035-4] [Medline: 14502403]

153. Bajka M, Tuchschmid S, Streich M, Fink D, Székely G, Harders M. Evaluation of a new virtual-reality training simulator for hysteroscopy. Surg Endosc 2009 Sep;23(9):2026-2033. [doi: 10.1007/s00464-008-9927-7] [Medline: 18437471]

154. Ayodeji ID, Schijven M, Jakimowicz J, Greve JW. Face validation of the Simbionix LAP Mentor virtual reality training module and its applicability in the surgical curriculum. Surg Endosc 2007 Sep;21(9):1641-1649. [doi: 10.1007/s00464-007-9219-7] [Medline: 17356944]

155. Schijven MP, Jakimowicz JJ. Validation of virtual reality simulators: key to the successful integration of a novel teaching technology into minimal access surgery. Minim Invasive Ther Allied Technol 2005;14(4):244-246. [doi: 10.1080/13645700500221881] [Medline: 16754170]

156. American Educational Research Association, American Psychological Association, National Council on Measurement in Education. Standards for Educational and Psychological Testing. Washington, DC: American Educational Research Association; 2014.

157. Korndorffer JR, Kasten SJ, Downing SM. A call for the utilization of consensus standards in the surgical education literature. Am J Surg 2010 Jan;199(1):99-104. [doi: 10.1016/j.amjsurg.2009.08.018] [Medline: 20103073] 
158. Nicholson WJ, Cates CU, Patel AD, Niazi K, Palmer S, Helmy T, et al. Face and content validation of virtual reality simulation for carotid angiography: results from the first 100 physicians attending the emory neuroanatomy carotid training (ENACT) program. Simul Healthc 2006;1(3):147-150. [doi: 10.1097/01.sih.0000244457.30080.fc] [Medline: 19088583]

159. McDougall EM, Corica FA, Boker JR, Sala LG, Stoliar G, Borin JF, et al. Construct validity testing of a laparoscopic surgical simulator. J Am Coll Surg 2006 May;202(5):779-787. [doi: 10.1016/j.jamcollsurg.2006.01.004] [Medline: 16648018]

160. Goodwin LD. Changing conceptions of measurement validity: an update on the new standards. J Nurs Educ 2002 Mar;41(3):100-106. [Medline: 11939227]

161. Straub D, Gefen D. Validation guidelines for IS positivist research. Commun Assoc Inf Syst 2004;13:-. [doi: 10.17705/1CAIS.01324]

162. Gallagher A, O'Sullivan G. Metrics for the measurement of skill. In: Fundamentals of Surgical Simulation: Principles and Practice. London, UK: Springer London; 2012:123-153.

163. Fried GM. Simulators for laparoscopic surgery: a coming of age. Asian J Surg 2004 Jan;27(1):1-3 [FREE Full text] [doi: 10.1016/S1015-9584(09)60235-9] [Medline: 14709418]

164. Schijven M, Jakimowicz J. Face-, expert, and referent validity of the Xitact LS500 laparoscopy simulator. Surg Endosc 2002 Dec;16(12):1764-1770. [doi: 10.1007/s00464-001-9229-9] [Medline: 12098029]

165. Andreatta P, Gruppen L. Conceptualising and classifying validity evidence for simulation. Med Educ 2009 Nov;43(11):1028-1035. [doi: 10.1111/j.1365-2923.2009.03454.x] [Medline: 19874494]

166. Xiao D, Jakimowicz JJ, Albayrak A, Buzink SN, Botden SM, Goossens RH. Face, content, and construct validity of a novel portable ergonomic simulator for basic laparoscopic skills. J Surg Educ 2014;71(1):65-72. [doi: 10.1016/j.jsurg.2013.05.003] [Medline: 24411426]

167. Emam TA, Hanna GB, Kimber C, Dunkley P, Cuschieri A. Effect of intracorporeal-extracorporeal instrument length ratio on endoscopic task performance and surgeon movements. Arch Surg 2000 Jan;135(1):62-5; discussion 66. [doi: 10.1001/archsurg.135.1.62] [Medline: 10636349]

168. Messick S. Standards of validity and the validity of standards in performance assessment. Educ Meas Issues Pract 1995;14(4):5-8. [doi: 10.1111/j.1745-3992.1995.tb00881.x]

169. Downing SM. Validity: on meaningful interpretation of assessment data. Med Educ 2003 Sep;37(9):830-837. [doi: 10.1046/j.1365-2923.2003.01594.x] [Medline: 14506816]

170. Moldovanu R, Târcoveanu E, Dimofte G, Lupaşcu C, Bradea C. Preoperative warm-up using a virtual reality simulator. JSLS 2011;15(4):533-538 [FREE Full text] [doi: 10.4293/108680811X13176785204409] [Medline: 22643511]

171. Calatayud D, Arora S, Aggarwal R, Kruglikova I, Schulze S, Funch-Jensen P, et al. Warm-up in a virtual reality environment improves performance in the operating room. Ann Surg 2010 Jun;251(6):1181-1185. [doi: 10.1097/SLA.0b013e3181deb630] [Medline: 20485133]

172. Abdalla G, Moran-Atkin E, Chen G, Schweitzer MA, Magnuson TH, Steele KE. The effect of warm-up on surgical performance: a systematic review. Surg Endosc 2015 Jun;29(6):1259-1269. [doi: 10.1007/s00464-014-3811-4] [Medline: 25149639]

173. Kahol K, Satava RM, Ferrara J, Smith ML. Effect of short-term pretrial practice on surgical proficiency in simulated environments: a randomized trial of the 'preoperative warm-up' effect. J Am Coll Surg 2009 Feb;208(2):255-268. [doi: 10.1016/i.jamcollsurg.2008.09.029] [Medline: 19228538]

174. Moran-Atkin E, Abdalla G, Chen G, Magnuson TH, Lidor AO, Schweitzer MA, et al. Preoperative warm-up the key to improved resident technique: a randomized study. Surg Endosc 2015 May;29(5):1057-1063. [doi:

10.1007/s00464-014-3778-1] [Medline: 25249142]

175. Pike TW, Pathak S, Mushtaq F, Wilkie RM, Mon-Williams M, Lodge JP. A systematic examination of preoperative surgery warm-up routines. Surg Endosc 2017 May;31(5):2202-2214. [doi: 10.1007/s00464-016-5218-x] [Medline: 27633438]

176. Chen CC, Green IC, Colbert-Getz JM, Steele K, Chou B, Lawson SM, et al. Warm-up on a simulator improves residents' performance in laparoscopic surgery: a randomized trial. Int Urogynecol J 2013 Oct;24(10):1615-1622. [doi: 10.1007/s00192-013-2066-2] [Medline: 23575698]

177. Plerhoples TA, Zak Y, Hernandez-Boussard T, Lau J. Another use of the mobile device: warm-up for laparoscopic surgery. J Surg Res 2011 Oct;170(2):185-188. [doi: 10.1016/j.jss.2011.03.015] [Medline: 21529831]

178. Soler L, Marescaux J. Patient-specific surgical simulation. World J Surg 2008 Feb;32(2):208-212. [doi: 10.1007/s00268-007-9329-3] [Medline: 18066615$]$

179. Marescaux J, Clément JM, Tassetti V, Koehl C, Cotin S, Russier Y, et al. Virtual reality applied to hepatic surgery simulation: the next revolution. Ann Surg 1998 Nov;228(5):627-634. [doi: 10.1097/00000658-199811000-00001] [Medline: 9833800]

180. Shiozawa M, Sata N, Endo K, Koizumi M, Yasuda Y, Nagai H, et al. Preoperative virtual simulation of adrenal tumors. Abdom Imaging 2009;34(1):113-120. [doi: 10.1007/s00261-008-9364-z] [Medline: 18253779]

181. Willaert WI, Aggarwal R, Van Herzeele I, Cheshire NJ, Vermassen FE. Recent advancements in medical simulation: patient-specific virtual reality simulation. World J Surg 2012 Jul;36(7):1703-1712. [doi: 10.1007/s00268-012-1489-0] [Medline: 22532308] 
182. Endo K, Sata N, Ishiguro Y, Miki A, Sasanuma H, Sakuma Y, et al. A patient-specific surgical simulator using preoperative imaging data: an interactive simulator using a three-dimensional tactile mouse. J Comput Surg 2014 Aug 6;1(1):-. [doi: 10.1186/s40244-014-0010-5]

183. Makiyama K, Yamanaka H, Ueno D, Ohsaka K, Sano F, Nakaigawa N, et al. Validation of a patient-specific simulator for laparoscopic renal surgery. Int J Urol 2015 Jun;22(6):572-576 [FREE Full text] [doi: 10.1111/iju.12737] [Medline: 25721949]

\section{Abbreviations}

MIS: minimally invasive surgery

MIST-VR: minimally invasive surgery training — virtual reality

LMC: Leap Motion Controller

DBR: design-based research

SIMISGEST-VR: gesture-mediated simulator for minimally invasive surgery-virtual reality

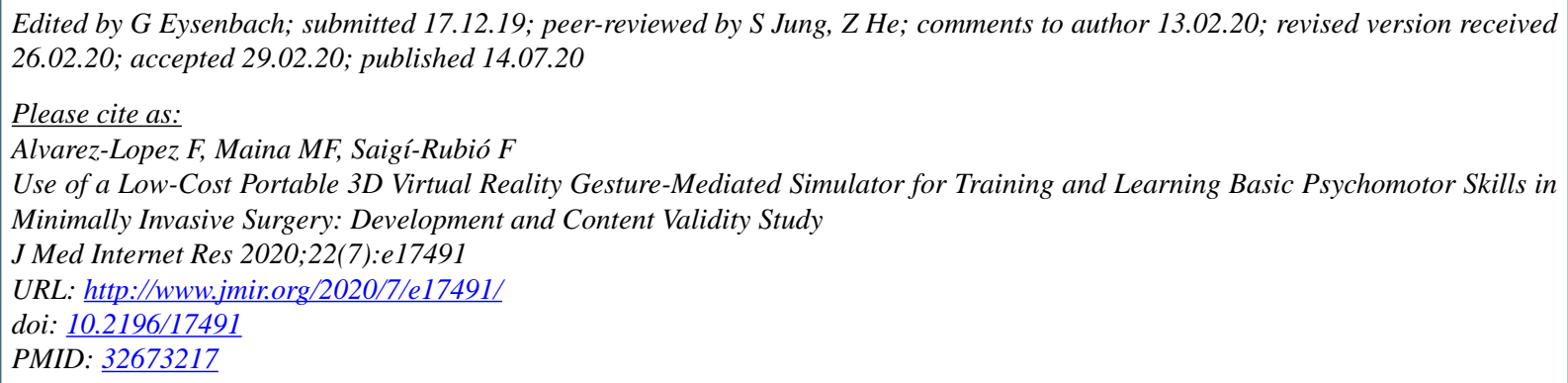

(CFernando Alvarez-Lopez, Marcelo Fabián Maina, Francesc Saigí-Rubió. Originally published in the Journal of Medical Internet Research (http://www.jmir.org), 14.07.2020. This is an open-access article distributed under the terms of the Creative Commons Attribution License (https://creativecommons.org/licenses/by/4.0/), which permits unrestricted use, distribution, and reproduction in any medium, provided the original work, first published in the Journal of Medical Internet Research, is properly cited. The complete bibliographic information, a link to the original publication on http://www.jmir.org/, as well as this copyright and license information must be included. 